\title{
Slope failure in underconsolidated soft soils during the development of a port in Tianjin, China. Part 1: Field investigation
}

\author{
S. Li, Z.Q. Yue, L.G. Tham, C.F. Lee, and S.W. Yan
}

\begin{abstract}
This paper presents the field investigation of a major landslide that occurred in a newly dredged slope for port development in the city of Tianjin, northern China. The dredged slope comprised underconsolidated soft clay of recent marine and river delta deposits. The landslide consisted of a number of individual slides that occurred sequentially and extended retrogressively and laterally into reclaimed land. It lasted for about $1 \mathrm{~h}$, occupying a plan area that is about $200 \mathrm{~m}$ long and $150 \mathrm{~m}$ wide in the reclaimed land. The failed soil mass was estimated to have a volume of between 700000 and $800000 \mathrm{~m}^{3}$. Part of the failed soil mass slipped into a newly dredged open space in the sea. The distance of the debris travel into the berth was about $80 \mathrm{~m}$. The debris surface had a gentle slope of about $3.0^{\circ}$. The angle from the dredged slope crest to the far edge of the debris was about $6.8^{\circ}$. A common rupture surface was found underneath the debris and above the in situ marine mud. It controlled the inland extension of the slope failure. The landslide occupied an inclined area of between 27000 and $30000 \mathrm{~m}^{2}$, with an overall slope angle of about $3-4^{\circ}$. A kinematic model is proposed to explain the extension of the landslide into the reclaimed land. Findings of this field investigation are further used in the companion paper for a theoretical investigation of the mechanism of the landslide. The engineering approach and results presented in this study could be useful in the design and construction of dredged slopes in underconsolidated soft soils.
\end{abstract}

Key words: port development, land reclamation, dredge excavation, landslide investigation, soft soils, case studies.

Résumé : Cet article présente l'étude sur le terrain d'un glissement de terrain important qui s'est produit dans un talus nouvellement dragué pour le développement du port de la Cité de Tianjin dans le nord de la Chine. Le talus dragué comprenait de l'argile molle sous-consolidée de dépôts marins récents et de bouche de delta de rivière. Le glissement de terrain consistait en un nombre de glissements individuels qui se sont produits en séquence et se sont étendus en rétrogression et latéralement dans un terrain de remblayage en mer. Il a duré environ $1 \mathrm{~h}$ et occupait une surface en plan d'environ $200 \mathrm{~m}$ de longueur par $150 \mathrm{~m}$ de largeur dans le remblai en mer. Le volume de la masse de sol impliquée dans le glissement a été estimée entre 700000 et $800000 \mathrm{~m}^{3}$. Une partie de la masse a glissé dans un espace dragué ouvert dans la mer. La distance de parcours dans le fond a été d'environ $80 \mathrm{~m}$. La surface des débris avait une faible pente d'environ $3,0^{\circ}$. L'angle à partir de la crête de la pente draguée jusqu'au bord éloigné des débris était d'environ $6,8^{\circ}$. On a trouvé une surface de rupture commune sous les débris et au-dessus de la vase marine in situ. Elle contrôlait l'extension de la rupture du talus à l'intérieur des terres. Le glissement occupait une surface inclinée de $27000 \mathrm{~m}^{2}$ à $30000 \mathrm{~m}^{2}$, avec une pente globale d'environ $3^{\circ}$ à $4^{\circ}$. On propose un modèle cinématique pour expliquer l'extension du glissement dans le terrain de remblayage. Les observations de cette étude de terrain sont utilisées de nouveau dans l'article qui accompagne celui-ci et présente une étude théorique du mécanisme du glissement. L'approche d'ingénieur et les résultats présentés dans cette étude pourraient être utiles pour la conception et la construction de talus dragués dans des sols mous sous-consolidés.

Mots clés : développement de port, récupération de terrain, excavation par dragage, étude de glissement, sols mous, études de cas.

[Traduit par la Rédaction]

\section{Introduction}

Ports constitute the basic infrastructure projects that make such coastal cities as Hong Kong, Shanghai, and Tianjin ma- jor centres of trade and logistics in China, as well as Asia. Port development involves many large marine civil engineering projects. These often include the construction of reclaimed land areas, wharfs, berths, seawalls, and breakwa-

Received 15 August 2002. Accepted 27 May 2004. Published on the NRC Research Press Web site at http://cgj.nrc.ca on 1 March 2005.

S. Li and S.W. Yan. Geotechnical Engineering Institute, Tianjin University, Tianjin, China.

Z.Q. Yue, ${ }^{1}$ L.G. Tham, and C.F. Lee. Department of Civil Engineering, The University of Hong Kong, Pokfulam Road, Hong Kong, China.

${ }^{1}$ Corresponding author (e-mail: yueqzq@hkucc.hku.hk). 
Fig. 1. Location of Xingang Port on the west bank of Bo Hai Bay in Tianjin, northern China.

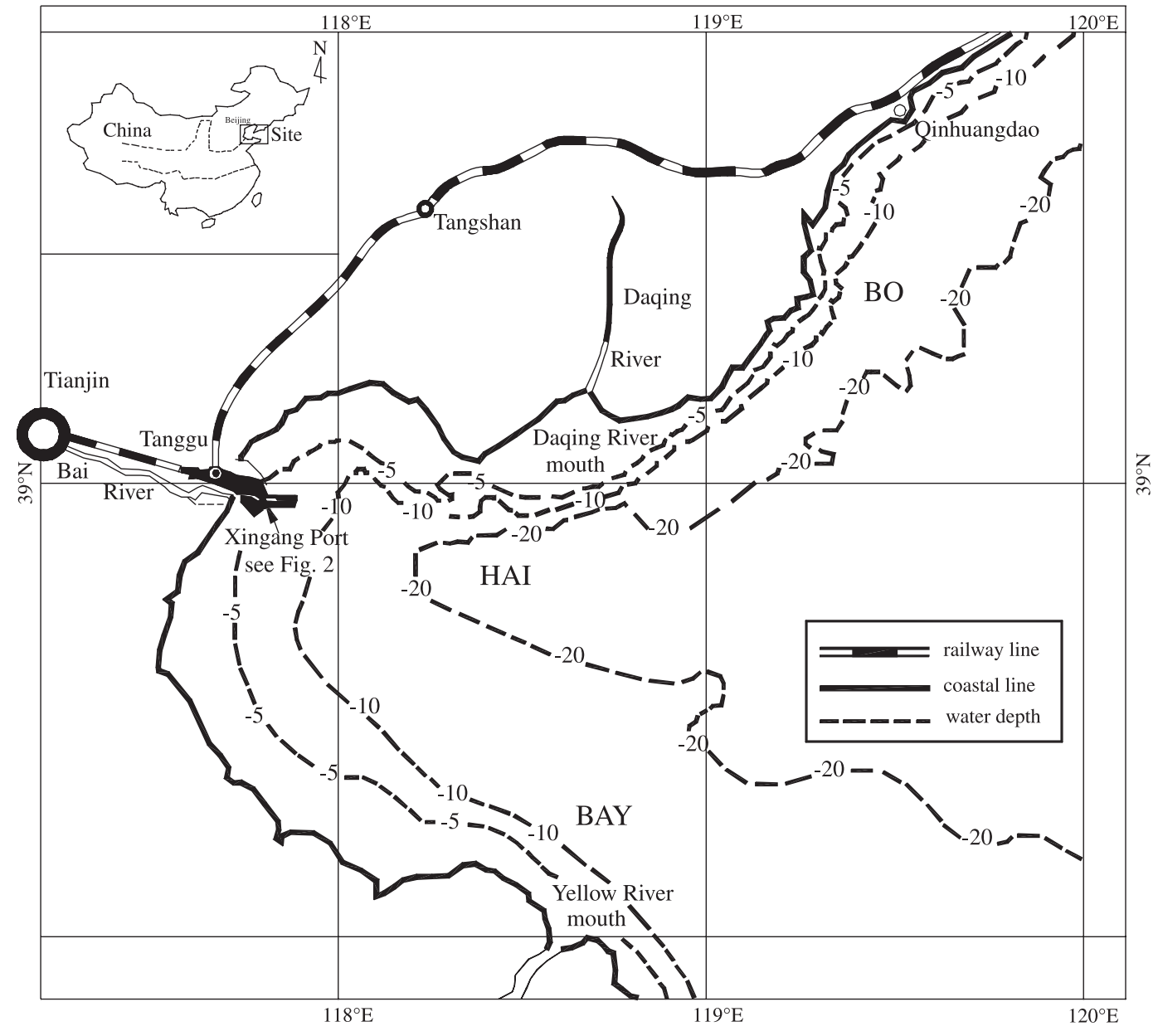

ters under difficult ground conditions and subject to wave action. Construction works often have to be carried out on saturated soft soils, such as recent marine and alluvial deposits, which are usually underconsolidated and have extremely low shear strength. One of the key engineering requirements is the dredging of the soft soils to provide temporary open space for seawall or breakwater construction or a permanent open space for berths and channels (BSI 1988, 2000; CEO 1996; Tsinker 1997). Inevitably, in this connection, temporary or permanent cut slopes would have to be formed in soft soils. A stability assessment of cut slopes comprising such underconsolidated soft soils is critical. It has been well recognized that for such soils, even small changes in the design parameters and methods could have significant technical and economical consequences (Lacasse 2001). For example, major slope failures involving underconsolidated marine mud have been reported in Hong Kong (GCO 1984a; Lam and Leung 1992; Endicott 2001).

A literature review indicates that tremendous efforts have been made in the assessment of slope stability in such soils (Morgenstern 1963; Janbu 1977; Skempton 1977; Lefebvre 1981; GCO 1984b; Roy and Leblanc 1988; Broms and Wong 1991; Fang and Mikroudis 1991; Lacasse 2001; Lee et al. 2001; Yue and Lee 2002). Slope stability analysis methods developed for general applications have also been adopted for stability assessments of marine slopes in underconsolidated soft soils (BSI 1988; CEO 1996; Tsinker 1997). In essence, the stability of such slopes can be assessed on the basis of either total or effective stress. Lacasse (2001) pointed out that total stress analysis may be considered for slopes comprising soils such as loose sand and quick clay, with great care needed in selecting the appropriate shear strength parameters.

In this paper and a companion paper ( $\mathrm{Li}$ et al. 2005), we present an engineering approach for an effective and accurate analysis of landslides in, and stability of, slopes cut in underconsolidated soft soils. The approach was developed during the investigation of a major landslide that occurred in a newly dredged slope during the construction of a long wharf. This submerged slope comprised underconsolidated soft soils of recent marine mud and alluvial deposits. In this paper, we present a field investigation of the landslide. The wharf development project is outlined first. We then give a detailed description of the landslide. Next, we present the results of the field investigation and further examine the kinematic mechanism of the landslide. In the companion paper ( $\mathrm{Li}$ et al. 2005), we present an analytical investigation of the landslide mechanism based on the findings in this paper. 
Fig. 2. Location of the landslide in Xingang Port.

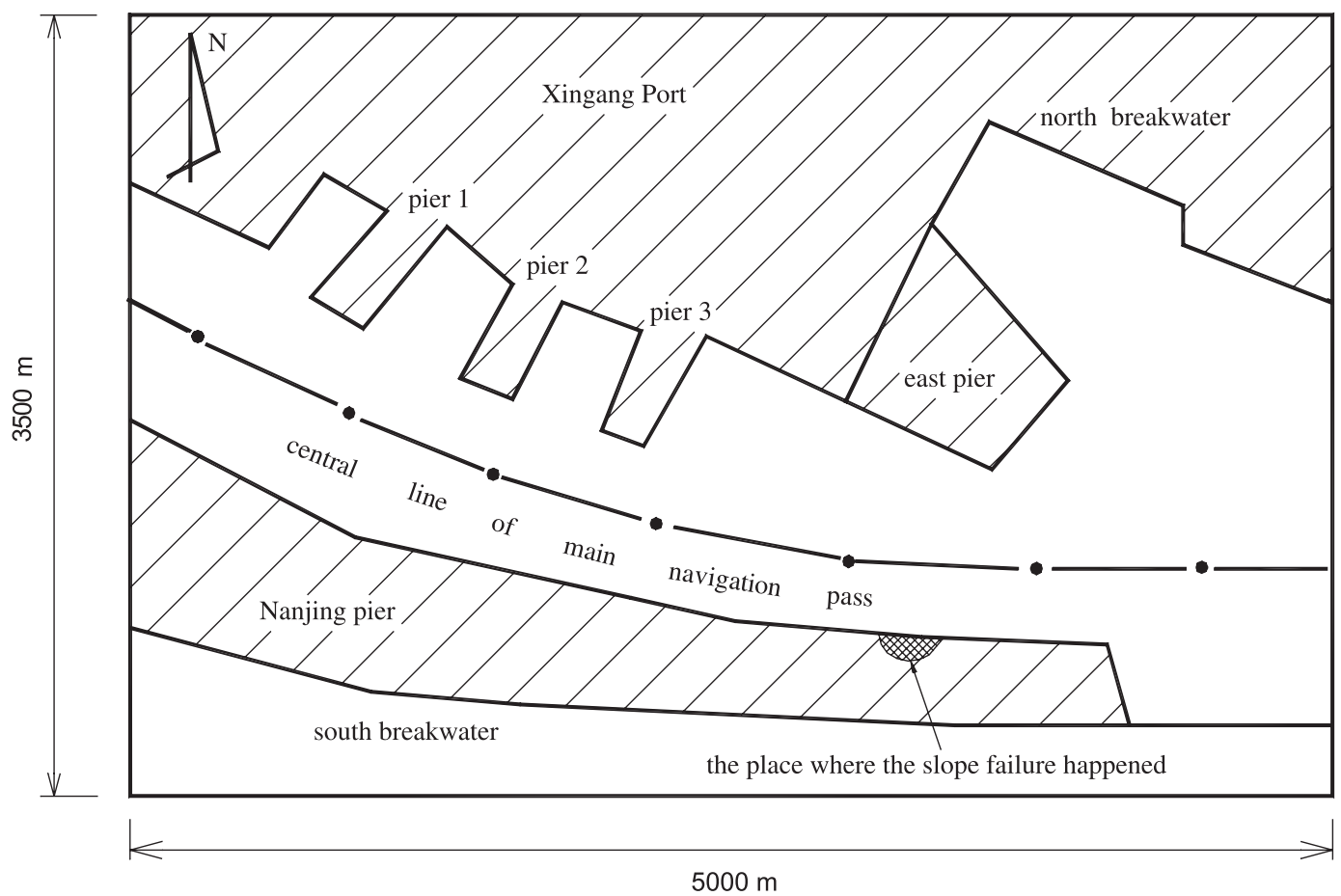

\section{Wharf construction project}

Figures 1 and 2 show the location of the landslide and the ongoing wharf development project on the western shoreline of Bo Hai Bay, near the city of Tianjin, northern China. This wharf development project is an extension of the existing Xingang Port (see Fig. 2). The wharf was designed to serve berth vessels of up to 35000 tons capacity and was constructed about $420 \mathrm{~m}$ from the central line of the main port navigation pass.

The entire Xingang Port is a man-made port occupying an area of $200 \mathrm{~km}^{2}$ on the sea and $25 \mathrm{~km}^{2}$ on land. Its land and seabed topography is extremely flat. The vertical/horizontal gradient of the land and seabed is less than 1:2000. Its navigation passes and berths have been developed and maintained by dredging the seabed. The dredged soft soils (i.e., hydraulic fills) have been used for land reclamation. The breakwaters are the main measures established to protect the port against the action of waves from the sea. Xingang Port can accommodate 100000 ton ships for navigation or anchoring.

The wharf development project involved the construction of the following major works:

(i) a reclamation dam of $4.4 \mathrm{~m}$ height and $434.5 \mathrm{~m}$ length on the seabed;

(ii) reclaimed land that is $4 \mathrm{~m}$ thick and $252 \mathrm{~m}$ wide along the shoreline and $434.5 \mathrm{~m}$ long in the sea, formed by hydraulic fill and contained within the reclamation dam;

(iii) a $13.8 \mathrm{~m}$ deep berth outside the dam and in the sea;

(iv) a dredged slope with a vertical/horizontal gradient of 1:2.2 from the dam to the berth;

(v) a wharf supported by driven piles above the reclaimed land, the dam, and the dredged slope to reach out to the ships in the berth; and (vi) terminal facilities on the land.

Figure 3 illustrates the general layout of the reclaimed land, the dam, the dredged (cut) slope, the berth, the installed piles, and the slipped land area. In Fig. 3, a rectangular coordinate system is used to illustrate the layout of the wharf construction. The horizontal axis is parallel to the shoreline of the dredged slope, in the west-east direction, and the vertical axis is perpendicular to the shoreline and toward the berth, in the south-north direction. This coordinate system was also used in the landslide investigation. Figure 4 illustrates a typical cross section of the wharf design. The dredged slope dipped toward the berth in a northerly direction.

The reclamation dam was constructed in 1991. It was made of stone blocks and shaped like a trapezium, with a height of $4.4 \mathrm{~m}$. Its base rested on the seabed, with an elevation of $0 \mathrm{~m}$ above mean sea level (a.m.s.l.). The $4 \mathrm{~m}$ thick land reclamation was completed in 1993, following the completion of the dam. Dredged mud from maintaining the port navigation passes was used for the land reclamation. The mud, in the form of slurry, was hydraulically transported to the reclamation area behind the dam. The slurry was then left in the reclaimed area to dry naturally.

After 4 years, the hydraulic fill soil in the reclaimed land still showed shear strength and bearing capacity that were still low for construction of terminal facilities. The conventional vacuum preloading technique was used to increase the soft fill strength and bearing capacity. General fills were then overlaid on the reclaimed land between 10 June and 15 July 1997. The general fill layer was $2.45 \mathrm{~m}$ thick and comprised mainly silty soils. A $0.4 \mathrm{~m}$ thick sand cushion was further overlaid on the general fill surface for the vacuum preloading. No engineered compaction was carried out on the general fill and the sand cushion. The fills were loose. 
Fig. 3. General layout of the wharf design and construction and the locations and orientations of the site photographs in Figs. 5, 6, and $8-11$.

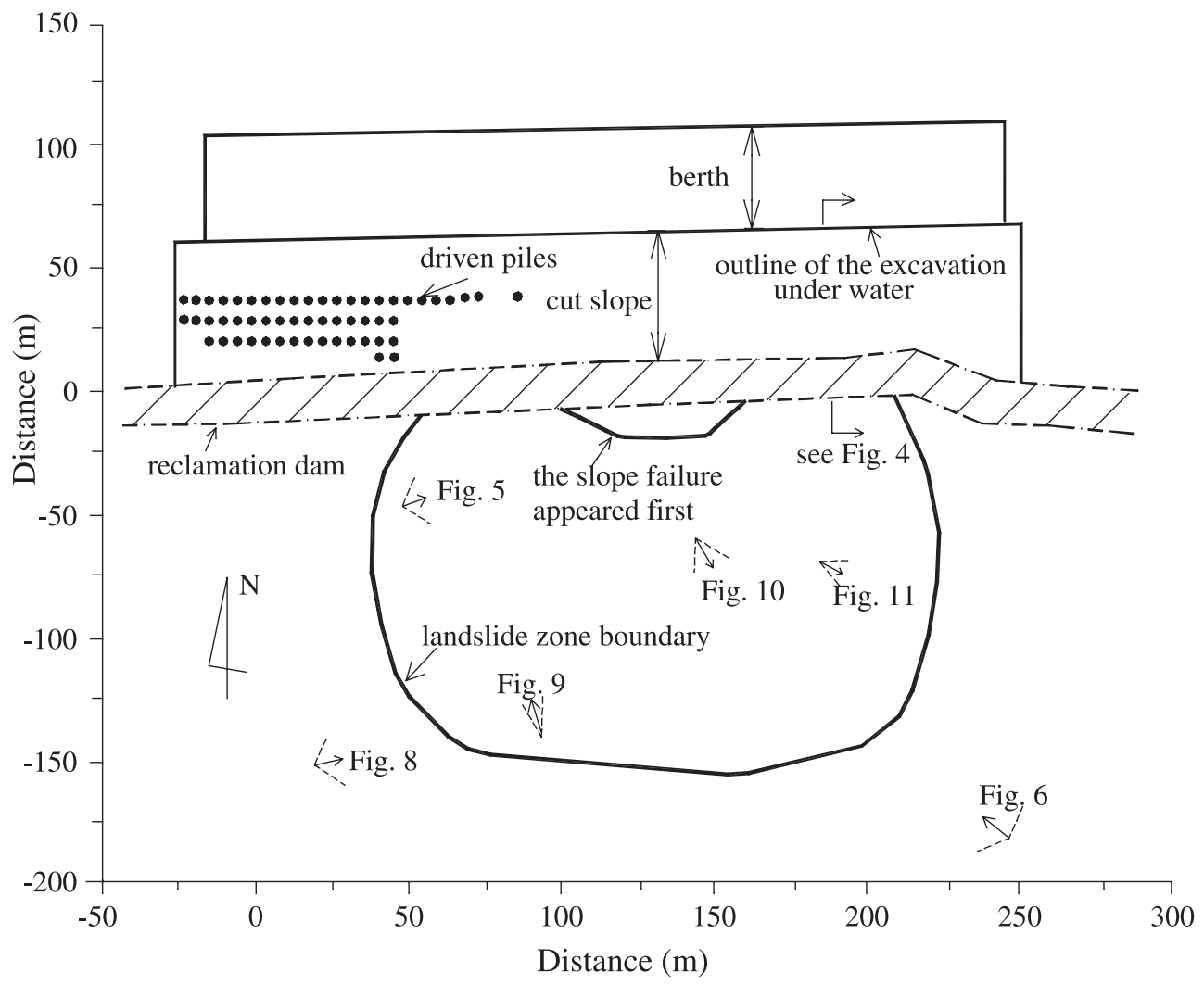

Fig. 4. Design cross section for wharf development.

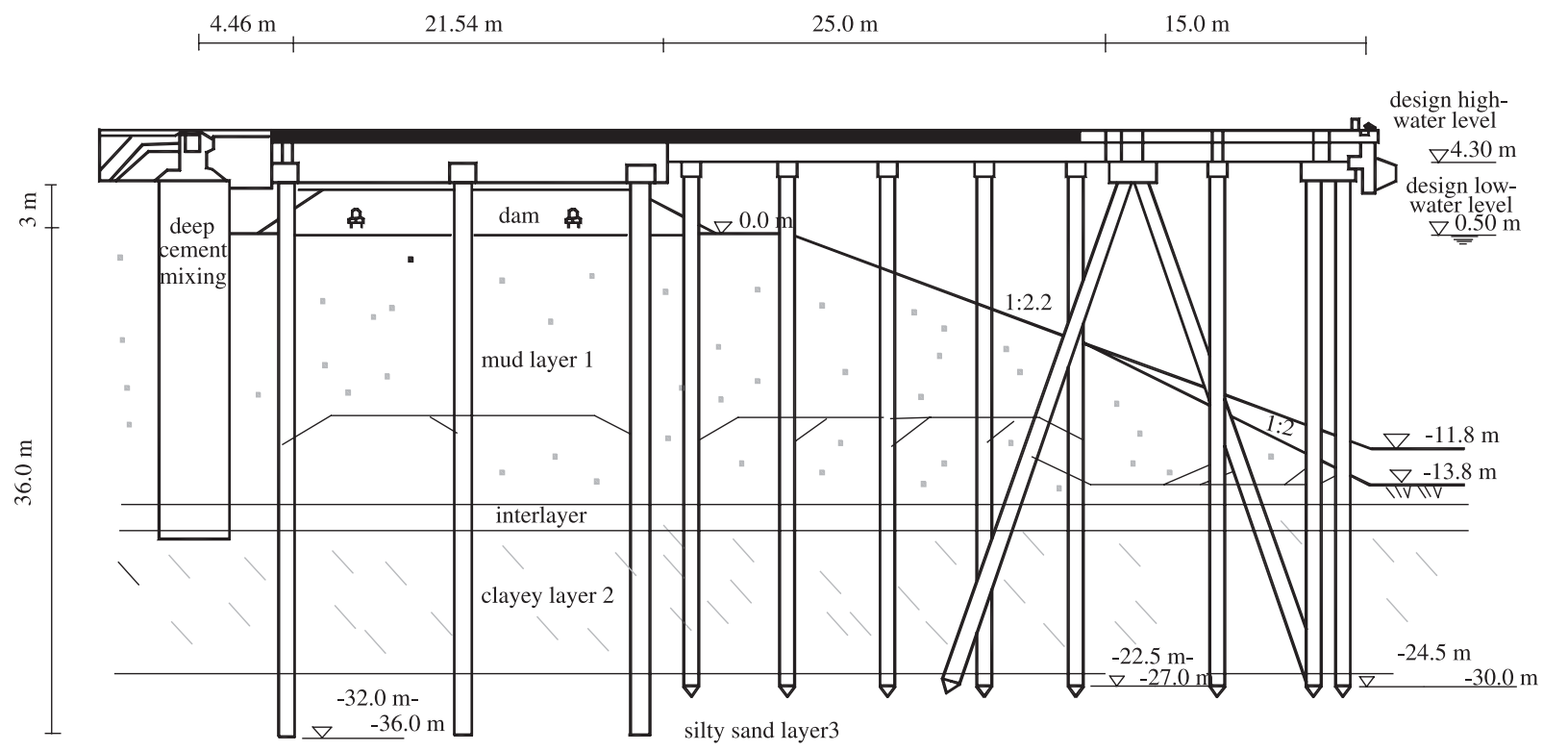

Dredge excavation for the formation of the dredged slope and the berth was started on 25 July and completed on 13 August 1997. On 15 August 1997, it was observed that the dredged slope gradient was unsatisfactory for the barge needed to install driven piles in the dredged slope. From 28
August to 4 September 1997, the original vertical/horizontal gradient of the lower portion of the dredged slope was revised from 1:2.2 to $1: 2$. In the meantime, a temporary road comprising $1.0 \mathrm{~m}$ thick residual soil was built on the reclaimed mud behind the dam. From 5 to 15 September 
Fig. 5. Site photograph showing the failed reclaimed area submerged in seawater during a tidal rise.

Remaining position of the reclamation dam

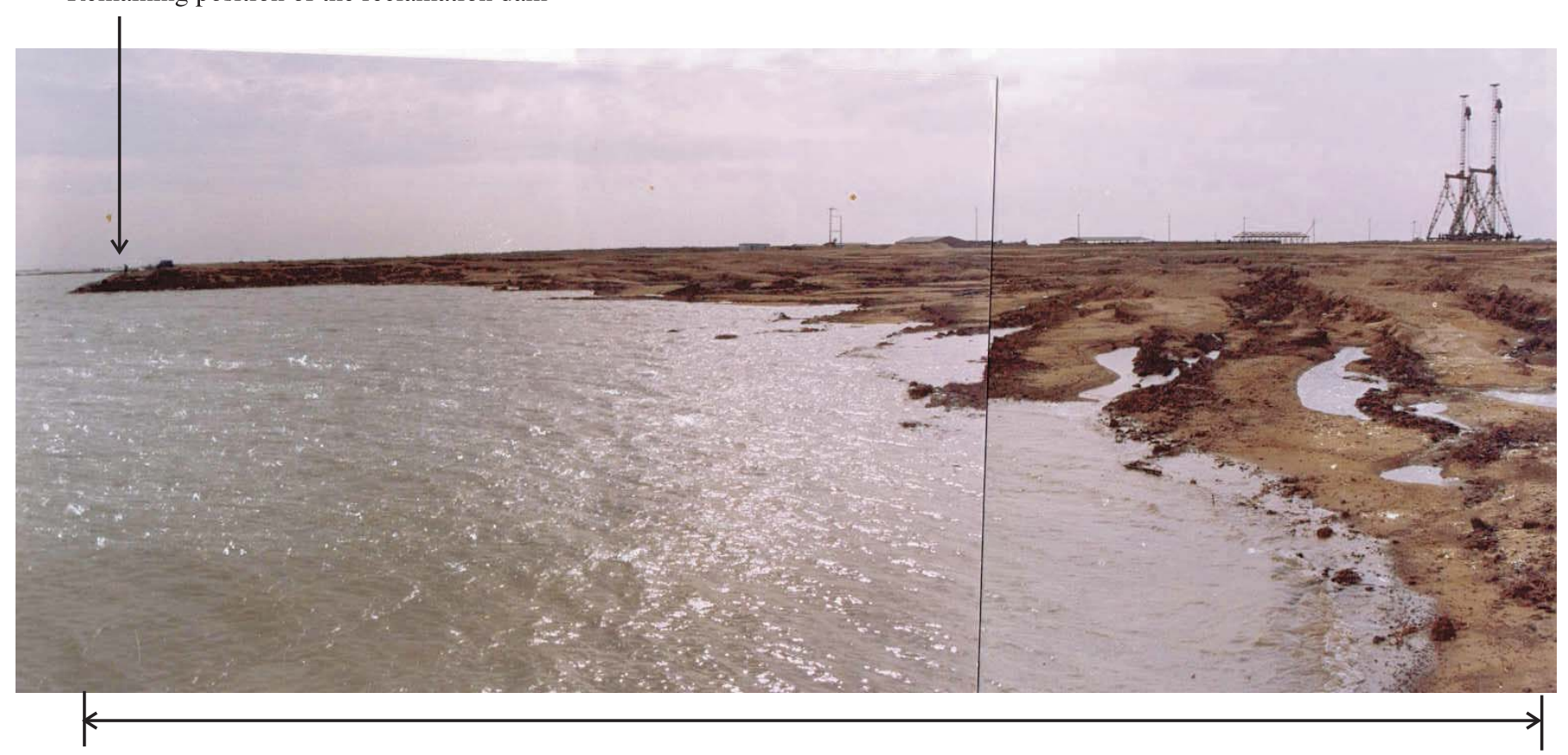

Landslide zone

1997, a total of 55 driven piles were installed in the dredged slope (see Fig. 3). No pile installation was carried out on 16 September 1997, the day before the landslide occurred.

\section{The landslide event}

According to witnesses, the landslide began at 09:00 on 17 September 1997 and lasted for about $1 \mathrm{~h}$. The landslide consisted of a number of sequential individual slides that extended retrogressively and spread laterally toward the reclaimed land.

A few hours before the first individual slide slipped into the sea, several deep tension cracks were observed in the backfill and the dam. This observation provided sufficient warning to the workers in temporary shelters, allowing them to leave the unstable zone in time. As a result, the landslide did not cause any fatality or injury.

The slip surface of the first slide was observed in the backfilled ground at about 10-20 m behind the reclamation dam. A wedge about $80 \mathrm{~m}$ long in a direction parallel to the shoreline and $30 \mathrm{~m}$ wide in a direction perpendicular to the shoreline slipped into the sea. After the occurrence of this first slide, the unstable zone then extended into the soil upslope and also spread laterally. Sequentially, a number of individual slides retrogressively occurred in the remaining reclaimed land behind the first slip surface and then slipped into the sea. The retrogressive sliding and lateral spreading lasted for about $1 \mathrm{~h}$. The 55 driven piles that had been installed in the western part of the dredged slope also moved and were inclined at various angles toward the berth during the landslide.

\section{Field investigation of the landslide}

\section{Visual inspection after the landslide}

A general view of the landslide zone and the surrounding reclaimed land can be observed in site photographs (Figs. 5 and 6). A more detailed view of the tension cracks in the reclaimed land above the seawater is provided in additional site photographs (Figs. 8-11). The location and the orientation of the site photographs are given in Fig. 3. The photographs were taken right after the landslide event and during a high tide.

From Figs. 5 and 6, it is evident that the main body of the landslide zone was submerged. The main failure zone became a seawater bay within the reclaimed land. Part of the landslide zone was above seawater. A number of long, arcuate tension cracks and slipped terraces could be clearly observed in the land portion of the landslide zone immediately above the seawater bay. These tension cracks and slipped terraces followed the seawater boundary of the submerged failure zone.

The plan boundary of the entire landslide zone in the reclaimed land behind the dam is identified in Figs. 3 and 7. From the plan boundaries of the dredged slope and berth area in Fig. 3, it is clear that the landslide occurred in the central region of the dredged slope along the shoreline. Furthermore, the main direction of the landslide was toward the north, where the berth was located.

In Figs. 8-11, it can be seen that the widths and depths of the arcuate tension cracks in the reclaimed land above the seawater are variable. The tension cracks had their nonsmooth surfaces dipping toward the centre of the seawater bay. Seawater could also be observed in some cracks 


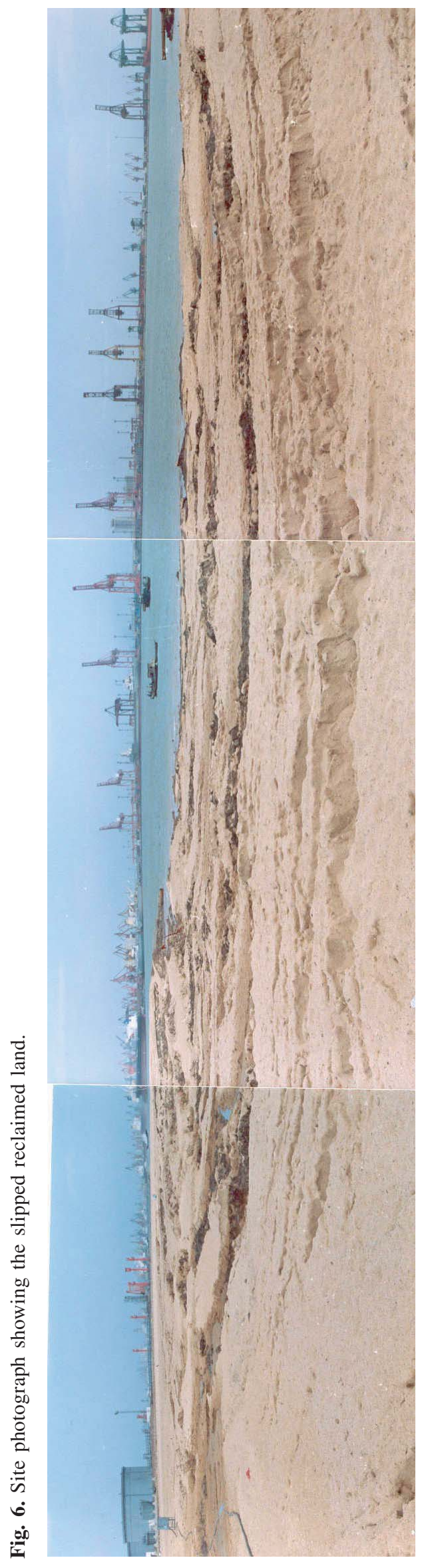

(Fig. 9). The slipped soils in front of the tension cracks took the form of a number of terraces. The terraces were about 5$10 \mathrm{~m}$ wide and had different heights. In general, the terraces heights were greater in the central region of the landslide zone and less in the two side regions. The central region includes cross sections $\mathrm{B}-\mathrm{B}, \mathrm{C}-\mathrm{C}$, and $\mathrm{D}-\mathrm{D}$; and the two side regions, cross sections $\mathrm{A}-\mathrm{A}$ and $\mathrm{E}-\mathrm{E}$ (Fig. 7). In Figs. 10 and 11 , it is also evident that the sand cushion was overlaid on the general fill.

The topographical distribution of the slipped terraces and the associated tension cracks clearly show that the landslide was made up of a number of individual slides, which extended retrogressively and spread laterally into the reclaimed land.

\section{Topographies before and after the landslide}

Before the landslide, a topographical survey was carried out to check the dredge excavation of the slope and the berth for wharf construction. Results of the topographical survey are shown in Fig. 12 for a three-dimensional presentation of the submerged slope and berth areas before the landslide. From Fig. 12, it is evident that the dredged berth had a relatively flat base about $8 \mathrm{~m}$ below the mean sea level. The berth had a rectangular geometry. It was surrounded by the three dredged slopes on the eastern, southern, and western boundaries. The dredged slopes were about 12-13 m high. A majority of the dredged slopes were submerged in seawater.

A topographical survey was carried out immediately after the landslide to examine the submerged landslide debris. Figure 13 shows the three-dimensional topography of the remaining dredged slopes and the landslide debris submerged in the sea. Figure 14 shows the two-dimensional topography of the landslide zone and its surrounding area.

Comparing the topographies in Figs. 12-14, we can observe the changes in the ground surface profiles of the submerged slope and berth. The landslide occurred between 100 and $250 \mathrm{~m}$ along the shoreline coordinate. This region was the central region of the slope and berth. The western part of the slope and berth, between -50 and $100 \mathrm{~m}$ along the shoreline coordinate, was slightly affected by the landslide, whereas the eastern part of the slope and berth, between 250 and $300 \mathrm{~m}$ along the shoreline coordinate, was affected significantly. As noted above, there were 55 driven piles installed in the western part of the dredged slope (see Fig. 3). The much smaller degree of damage in the western part of the dredged slope may indicate that the driven piles had some stabilizing effect on the western dredged slope.

The landslide debris travel distance was about $80 \mathrm{~m}$ into the dredged open space in the sea. The landslide debris was deposited over an enlarged area in the berth and on the dredged slope. The overall slope of the landslide debris surface was very gentle and about $3.0^{\circ}$. The angle of the debris flow from the dredged slope crest to the far front of the debris deposit in the berth was about $6.8^{\circ}$. The runout distance normalized to the height drop was between 8.4 and 19.1 and was within the lower limits of recorded submarine slides comprising soft soils (Lacasse 2001). The depth of the berth base was increased from the original elevation of $-8 \mathrm{~m}$ a.m.s.l. to about $-4 \mathrm{~m}$ a.m.s.l. The debris was not uniformly deposited in the western and eastern regions of the berth. The eastern region of the berth had more debris deposition. 
Fig. 7. Location of boreholes and test holes before and after the landslide.

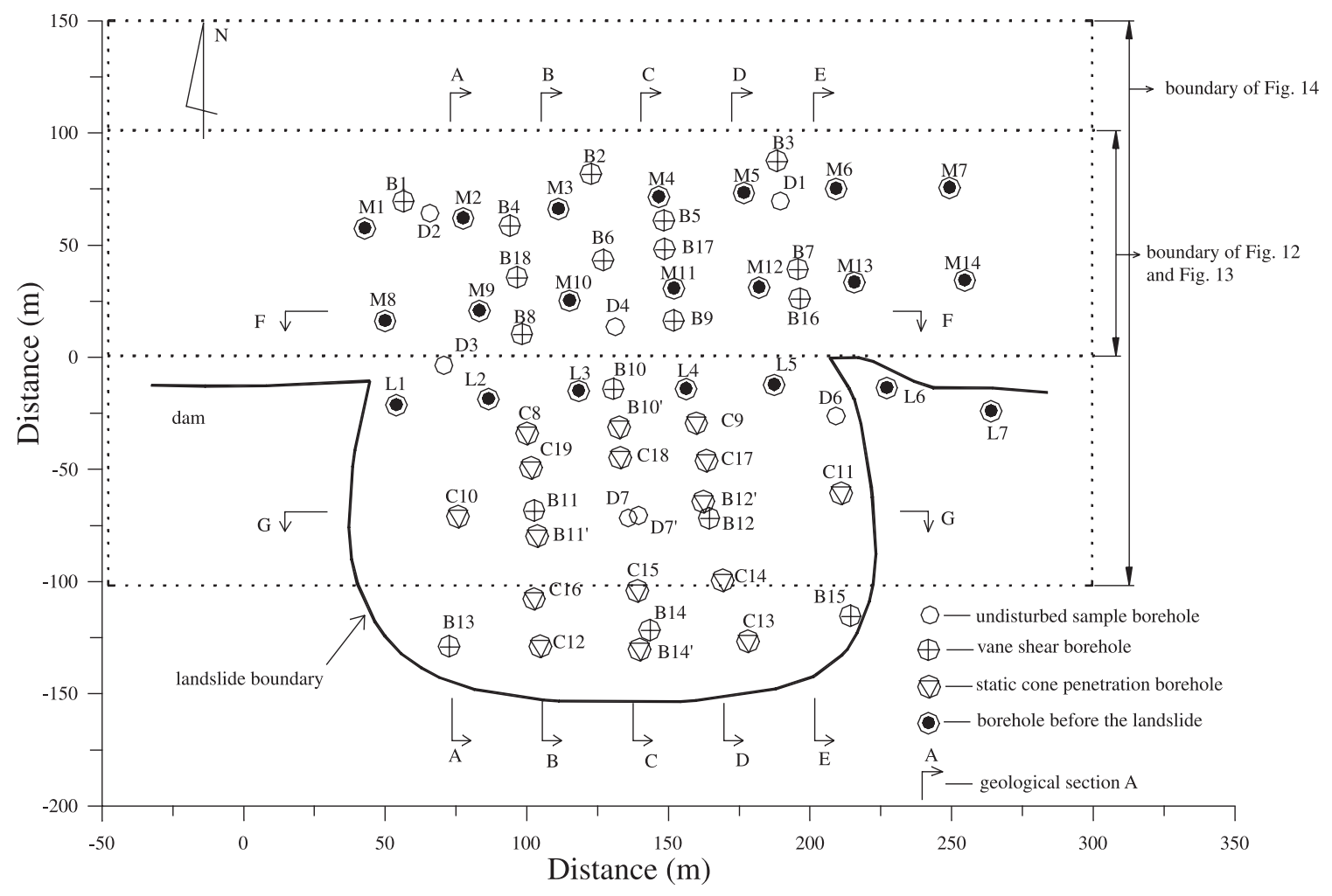

The debris was estimated to have occupied a volume of between 45000 and $60000 \mathrm{~m}^{3}$ on the base of the berth.

\section{Site geological setting}

The western shoreline region of the Bo Hai Bay is a typical mud coastal plain and has experienced continued land depression and sedimentation over the entire Cenozoic era (Hou 1987). The Cenozoic strata are more than $1000 \mathrm{~m}$ thick and are composed of marine and river-mouth alluvial deposits. The marine and alluvial deposits are interlayered.

A thick Holocene $\mathrm{Q}_{4}$ soft soil stratum forms the shoreline seabed. This soil stratum comprises mainly recent marine deposits, with some thin alluvial deposits. The source of the alluvial deposits was mainly the Hai He River, in the Tianjin region (see Fig. 1). The top of the $\mathrm{Q}_{4}$ stratum is a muddy silt layer of a shallow-water sedimentary environment. Its sedimentary age is about 300-400 years. It has its own fabric. Its sensitivity (i.e., the ratio between the peak shear strength and the residual shear strength) is of an intermediate degree. The lower portion of the $\mathrm{Q}_{4}$ stratum is a muddy clay layer of a deep-water sedimentary environment. This layer shows laminations. Its sedimentary age is about 2000 years. The soil also has a fabric.

The $\mathrm{Q}_{4}$ soft soil stratum is underlain by a thick silt to silty sand stratum. This stratum was formed in a river delta sedimentary environment. The source of the sedimentation was mainly the Yellow River (see Fig. 1). The silt layer has either horizontal laminations or interlaced laminations. This soil stratum is in a normally consolidated state and has a higher shear strength and a lower void ratio than the $Q_{4}$ soft soil strata.

\section{Ground investigation before and after the landslide}

Figure 7 shows the locations of the boreholes and the in situ tests carried out within the landslide zone before and after the landslide. Among these, 21 boreholes were carried out for soil sampling and field testing before the landslide for the design of the slope and berth by dredging. In particular, seven of the boreholes (M1, M3, M5, M6, L2, L4, and L6) were for undisturbed soil sampling, and six (M2, M4, M7, M9, M11, and M13) were for standard penetration tests (SPTs). The other eight holes were used for field vane tests. The conventional static cone penetration tests (CPTs) were not carried out before the landslide.

After the landslide, 41 boreholes were drilled: undisturbed soil sampling was carried out in 7 boreholes; field vane tests were carried out at 18; and CPTs were carried out at 16.

After completion of the ground investigation, soil samples were used in laboratory tests to determine the physical and mechanical properties of the soils encountered in the landslide zone. The undisturbed soil samples, combined with the results of the CPTs, SPTs, and vane tests, were used to determine the ground soil profile before and after the landslide. Results of the ground investigation will be discussed later.

\section{Soil profile before the landslide}

The ground conditions at the landslide site, as determined by the ground investigation, are shown in Figs. 4 and 15 . Figure 4 shows the simplified soil profile that was used for wharf design. Figure 15 shows a detailed soil profile that was refined with the use of the ground investigation data from before and after the landslide. The figure depicts the geological conditions along cross section $\mathrm{C}-\mathrm{C}$ in Figs. 7 and 14. This cross section is also the central line of the landslide 
Fig. 8. Site photograph showing long and arcuate tension cracks and slipped terraces in the reclaimed land.

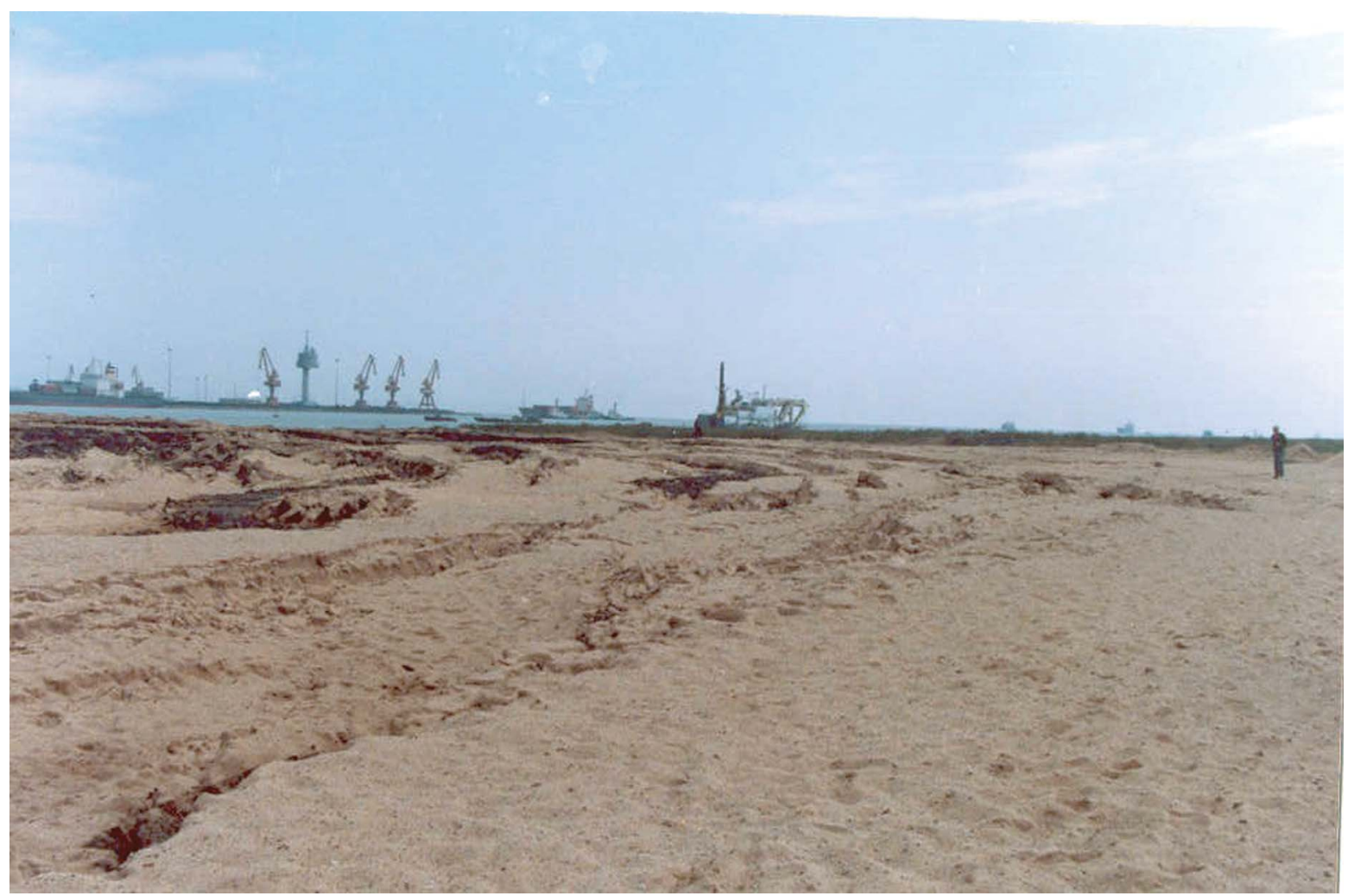

Fig. 9. Site photograph showing water in the tension cracks in the reclaimed land.

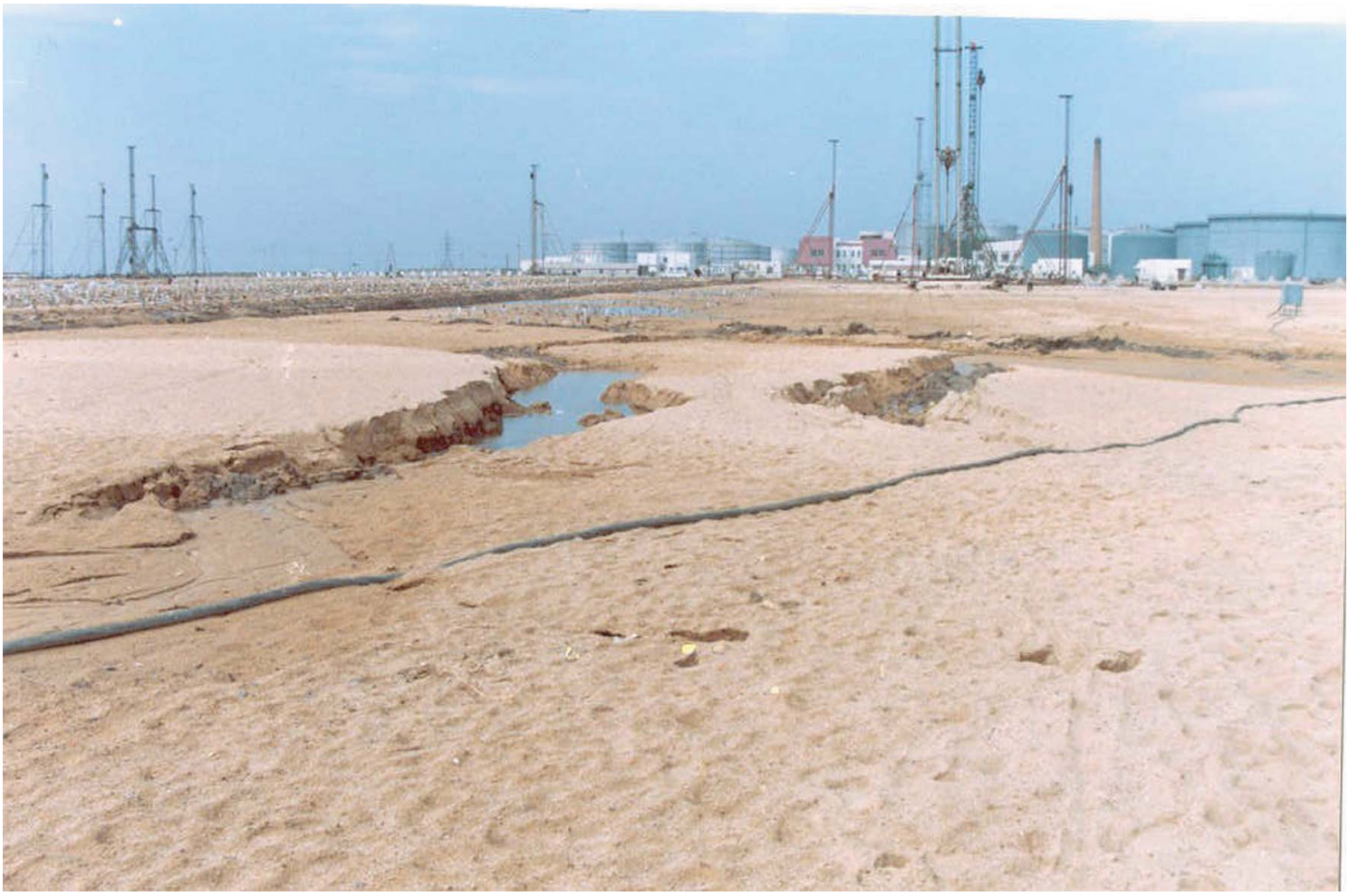

zone and represents the most critical geological section for assessing slope stability.

Figure 15 shows the existence of an artificial top layer above the in situ soils. This top layer comprised the general backfill soil and the thin sand cushion. The top surface of the hydraulic fill sublayer had become a hard shell because 
Fig. 10. Site photograph showing slipped terraces and their associated tension cracks in the reclaimed land.

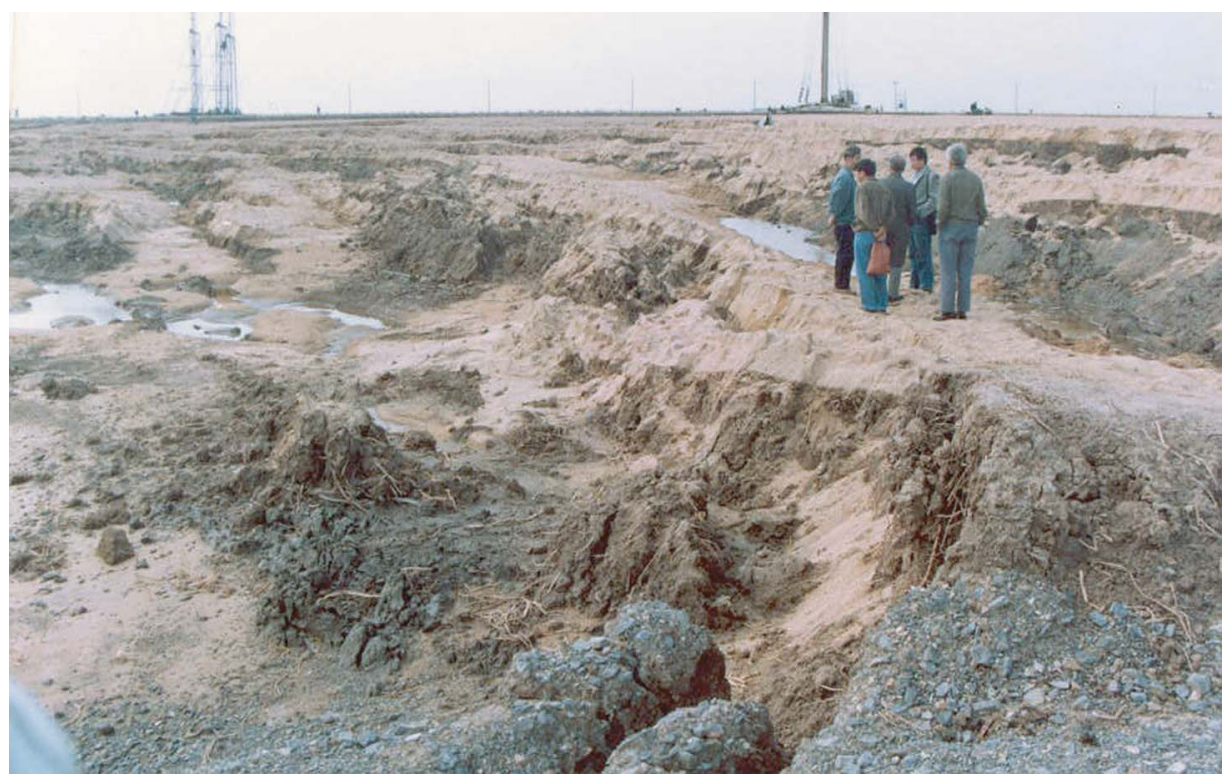

Fig. 11. Site photograph showing slipped terraces and their associated tension cracks in the reclaimed land.

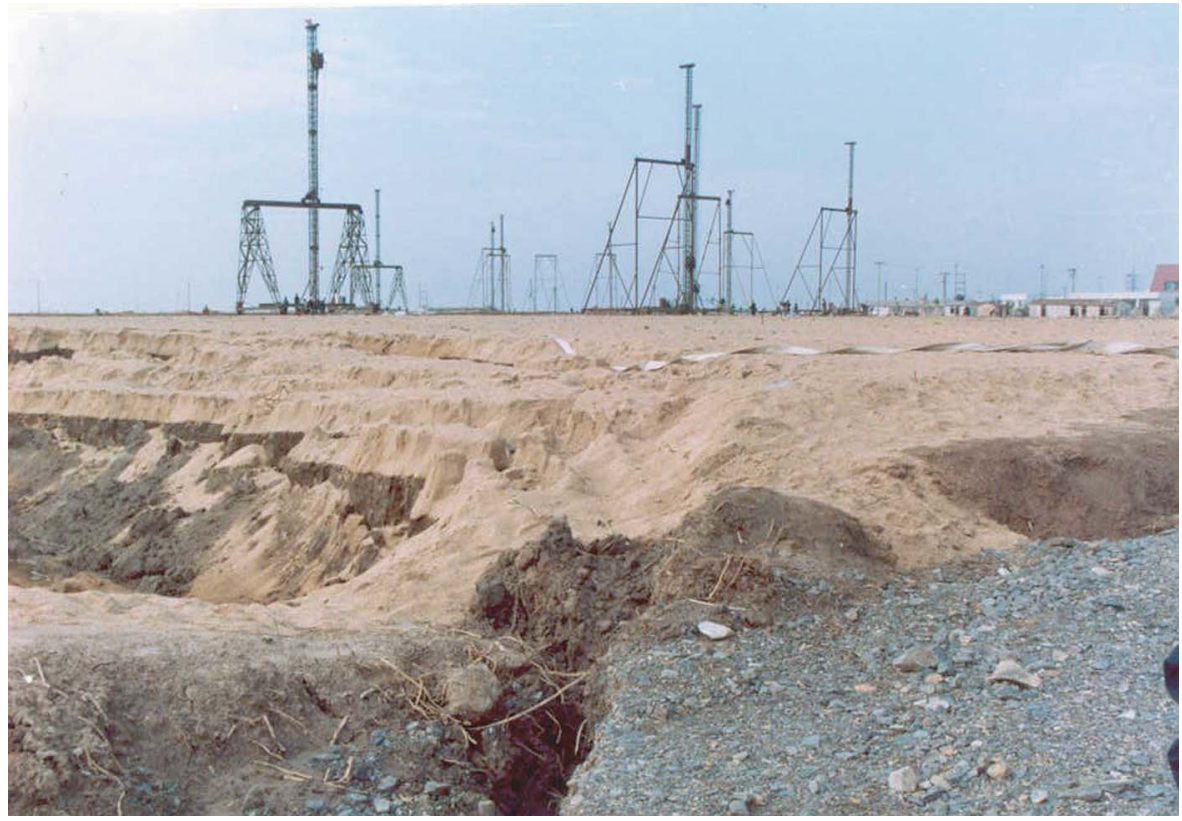

of the natural drying process between 1993 and 1997. Being made of a recent marine deposit, the hydraulic fill sublayer was not easily distinguished from the in situ recent marine deposit. Therefore, for engineering purposes, it was treated as part of in situ sublayer 1-1 of the recent marine mud deposit.

The in situ ground could be further classified into four soil layers (see Fig. 15). The first in situ soil layer, layer 1, was a recent marine mud deposit, of $14 \mathrm{~m}$ thickness. This layer could be further divided into three sublayers, according to physical and mechanical properties. The upper sublayer, 1-1, was a muddy silt of 2.0-7.0 m thickness. The muddy silt was mixed with thin sandy silt seams and had mud or muddy clay lenses. Occasionally, silty seams could also be found in this sublayer. The middle sublayer, 1-2, was a muddy soil of $3.0-6.0 \mathrm{~m}$ thickness. It was mixed with thin sandy silt seams and contained shells. A few muddy clay lenses were found in this middle sublayer as well. The bottom sublayer, 1-3, was a muddy clay soil and had a thickness of $5.0-13.0 \mathrm{~m}$. The muddy clay was mixed with the thin silty sand seams and contained organic matter or shells.

The second in situ soil layer, layer 2, was a clayey layer that could also be further divided into three sublayers. The upper sublayer, 2-1, was silt. Its thickness gradually decreased from the west to the east along the shoreline. It was mixed with thin clay or sandy silt seams or lenses. The middle sublayer, 2-2, was a 2.0-5.0 m thick clay. It was distributed mainly in the west wharf area. The bottom sublayer, 
Fig. 12. Three-dimensional topography of the dredged slope and berth submerged in seawater before the landslide.

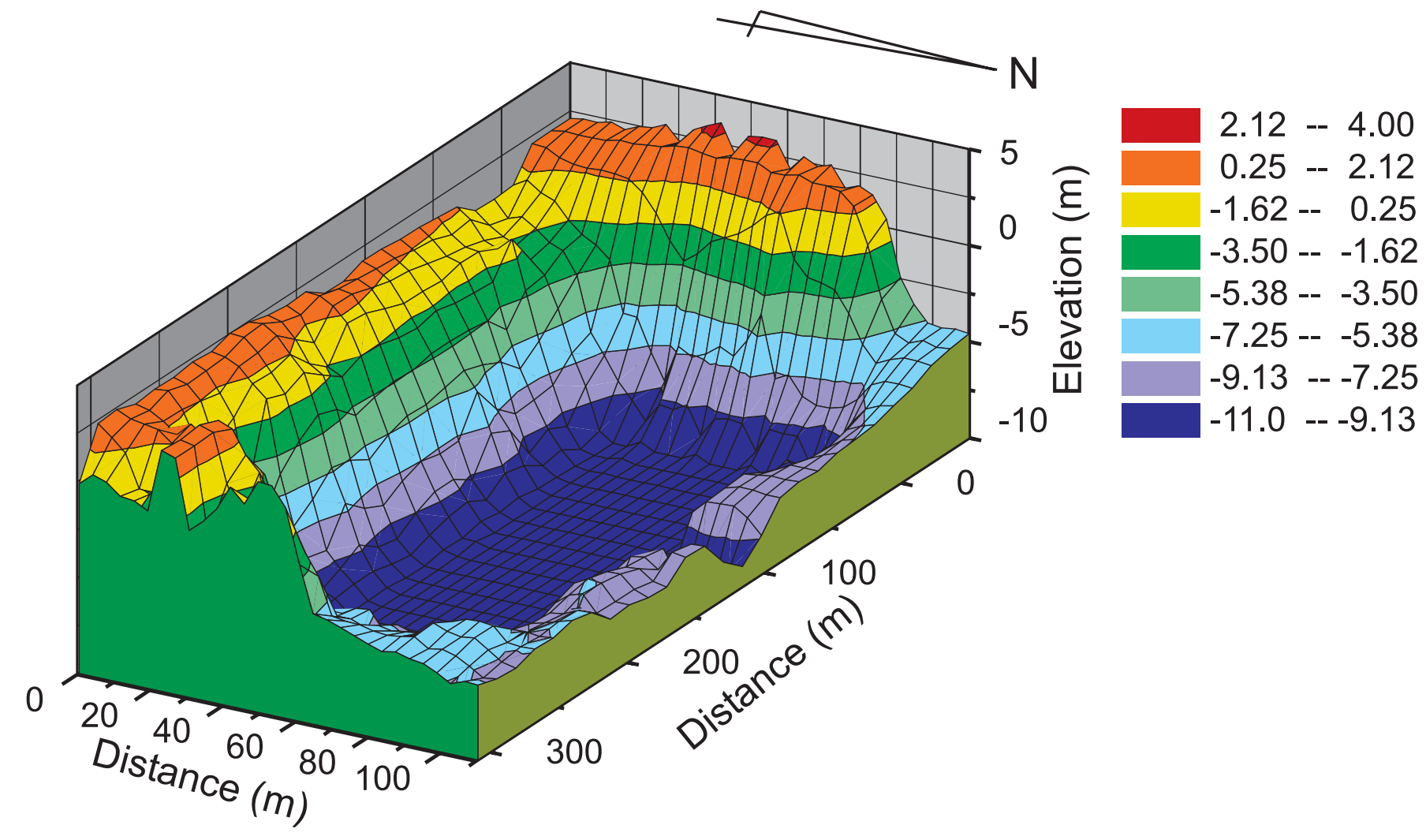

Fig. 13. Three-dimensional topography of the failed cut slope and berth submerged in seawater after the landslide.

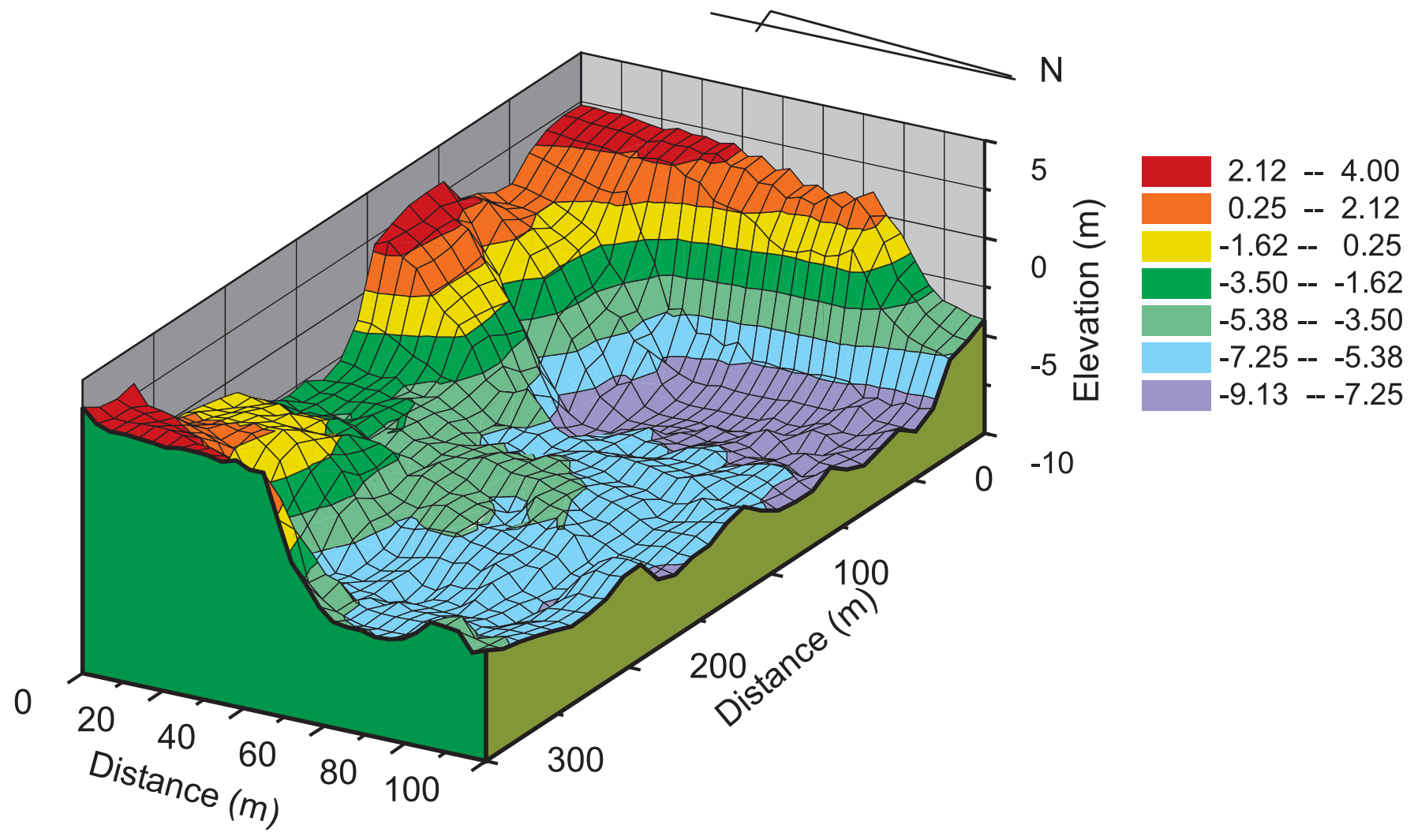


Fig. 14. Two-dimensional topography of the failed land in seawater and on land after the landslide.

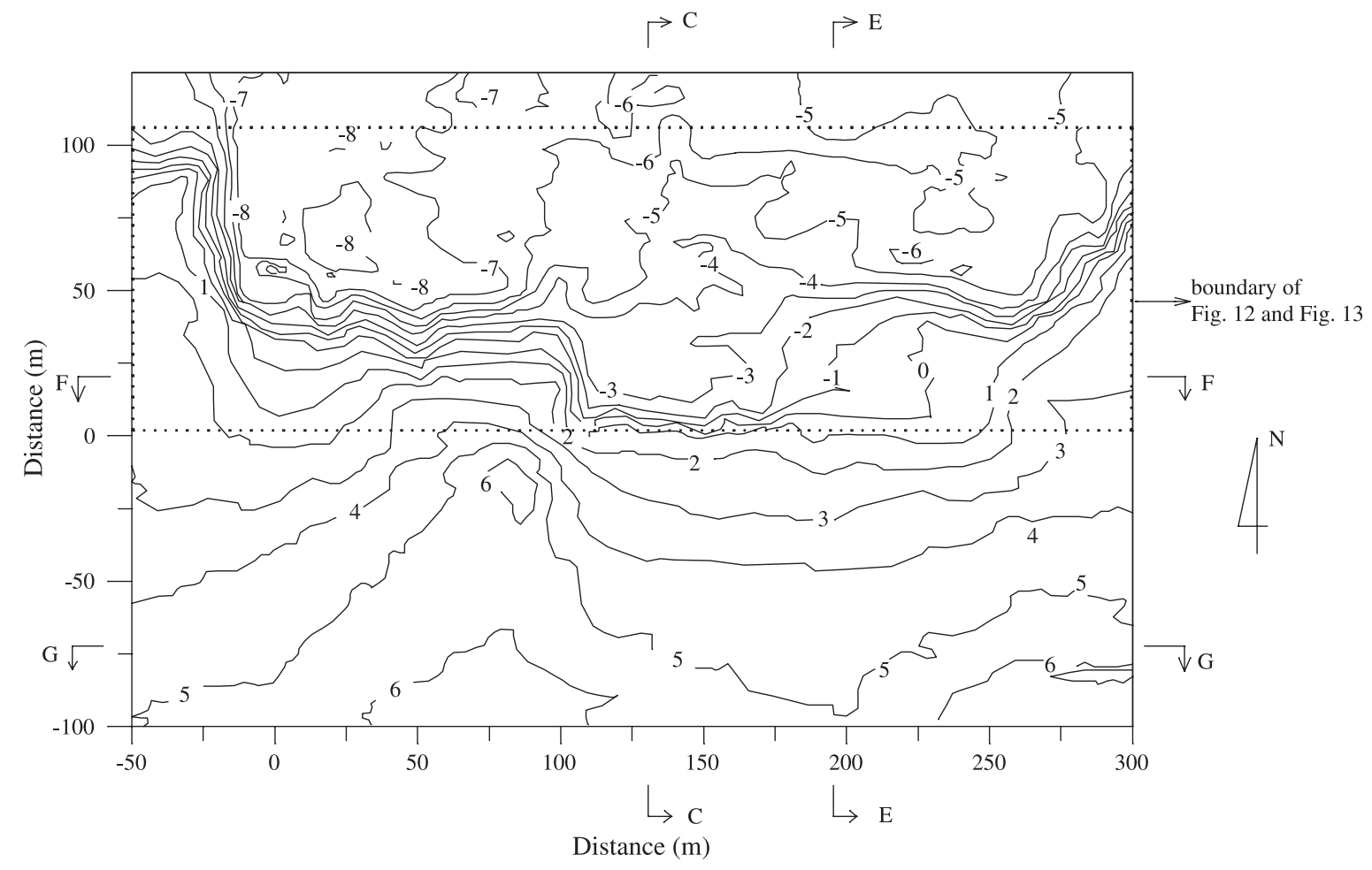

Fig. 15. Refined soil profile in the reclaimed land and dredged slope along cross section C-C.

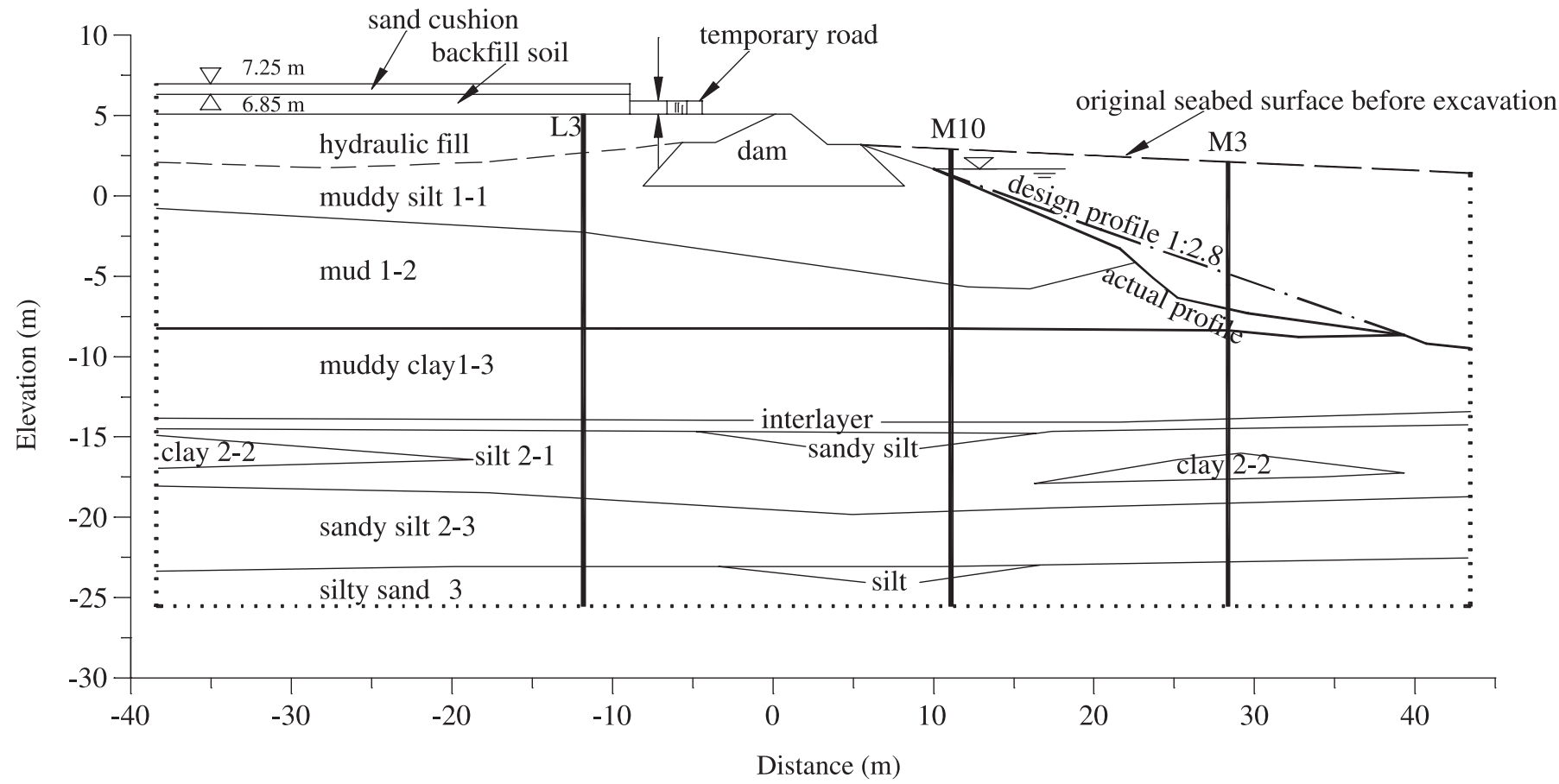

2-3, was a 1.0-5.0 m thick sandy silt, with much silty sand, and was distributed mainly in the eastern wharf area. Its distribution was not continuous and might appear as lenses or thin seams.

Between the first and second in situ soil layers was a $1 \mathrm{~m}$ thick silt interlayer. This interlayer comprised sand and shell mixes. The third in situ soil layer, layer 3, was a silty sand, which was normally consolidated and had a relatively high shear strength and bearing capacity. This layer was selected as the foundation soil for the driven piles, as shown in Fig. 4.

The ground investigation revealed that the soil profiles and slope geometries for cross sections A-A, B-B, C-C, D$\mathrm{D}$, and $\mathrm{E}-\mathrm{E}$ in Fig. 7 did not show significant differences. 
Table 1. Representative values of the soil physical properties.

\begin{tabular}{|c|c|c|c|c|c|c|c|}
\hline Soil layer & $\begin{array}{l}\text { Soil } \\
\text { layer } \\
\text { No. }\end{array}$ & $\begin{array}{l}\text { Water } \\
\text { content, } \\
\omega(\%)\end{array}$ & $\begin{array}{l}\text { Unit } \\
\text { weight, } \\
\gamma\left(\mathrm{kN} / \mathrm{m}^{3}\right)\end{array}$ & $\begin{array}{l}\text { Void } \\
\text { ratio, } \\
e\end{array}$ & $\begin{array}{l}\text { Liquid } \\
\text { limit, } \\
W_{\mathrm{I}}(\%)\end{array}$ & $\begin{array}{l}\text { Plasticity } \\
\text { index, } \\
I_{\mathrm{p}}\end{array}$ & $\begin{array}{l}\text { Liquidity } \\
\text { index, } \\
I_{\mathrm{I}}\end{array}$ \\
\hline Surface layer & & 28.6 & - & - & 43.7 & 22.4 & 0.3 \\
\hline Muddy silt & $1-1$ & 41.7 & 17.9 & 1.2 & 30.7 & 14.4 & 1.7 \\
\hline Mud & $1-2$ & 58.2 & 16.5 & 1.7 & 49.3 & 25.6 & 1.4 \\
\hline Muddy clay & $1-3$ & 46.6 & 17.5 & 1.3 & 42.9 & 22.0 & 1.2 \\
\hline Interlayer & & 25.4 & 19.6 & 0.8 & 28.8 & 12.7 & 0.7 \\
\hline Silt & $2-1$ & 26.1 & 19.7 & 0.7 & 29.1 & 11.1 & 0.7 \\
\hline Clay & $2-2$ & 34.7 & 18.7 & 1.0 & 41.0 & 20.7 & 0.7 \\
\hline Sandy silt & $2-3$ & 21.9 & 20.2 & 0.6 & 25.9 & 6.1 & 0.3 \\
\hline
\end{tabular}

Note: The values for the soil properties are average values from the actual soil tests.

Table 2. Representative values for the soil shear strengths.

\begin{tabular}{|c|c|c|c|c|c|c|c|c|c|c|c|c|c|}
\hline Soil layer & $\begin{array}{l}\text { Soil } \\
\text { layer } \\
\text { No. }\end{array}$ & \multicolumn{4}{|c|}{ Direct shear test } & \multicolumn{6}{|c|}{ Triaxial test } & $\underline{a_{1-2}}$ & SPT \\
\hline Muddy silt & $1-1$ & 1.0 & 7.7 & 19.0 & 18.0 & 0.8 & 5.0 & 17.0 & 15.5 & 29.2 & 19.5 & 0.7 & $<1$ \\
\hline Mud & $1-2$ & 1.1 & 9.0 & 14.4 & 12.0 & 0.9 & 10.7 & 13.0 & 10.0 & 18.0 & 18.0 & 1.4 & $<1$ \\
\hline Interlayer & & 17.5 & 17.9 & 23.0 & 20.0 & - & - & - & - & - & - & 0.4 & 4 \\
\hline Silt & $2-1$ & 20.9 & 21.0 & 25.7 & 21.0 & 4.8 & 47.0 & 21.0 & 50.0 & 34.0 & 36.0 & 0.2 & 12 \\
\hline Clay & $2-2$ & 8.4 & 28.0 & 19.5 & 23.0 & 1.8 & 33.0 & 16.5 & 37.0 & 24.0 & 31.0 & 0.5 & 7 \\
\hline Sandy silt & $2-3$ & 29.1 & 22.0 & 28.3 & 17.0 & - & - & - & - & - & - & 0.1 & 35 \\
\hline Silt sand & 3 & - & - & - & - & - & - & - & - & - & - & - & $>50$ \\
\hline
\end{tabular}

Note: The values of the shear strengths are average values of actual tests in the soil laboratory and in the field. $a_{1-2}$, soil compressibility; CD, consolidated drained; CUD, consolidated undrained; CUDD, consolidated undrained direct; UUD, unconsolidated undrained; UUDD, unconsolidated undrained direct; $c$, cohesion; $\varphi$, friction angle; $c^{\prime}$, effective cohesion; $\varphi^{\prime}$, effective friction angle.

Therefore, the soil profile for cross section $\mathrm{C}-\mathrm{C}$ in Fig. 15 was used as the representative geological model for the stability analysis and landslide investigation. It is further noted that the dredged slope and berth space were within the first in situ soft soil layer.

\section{Soil physical properties and shear strength}

Table 1 summarizes the physical properties of the soils encountered at the landslide site. It is evident that the in situ water content of the recent marine mud (i.e., of sublayers 11, 1-2, and 1-3) was greater than the liquid limit, and its void ratio was larger than 1.0.

In the landslide investigation, one of the important tasks was to determine the soil shear strength for slope stability analysis. A number of conventional soil shear strength tests were then conducted in the laboratory and in the field. The tests included the unconsolidated undrained direct (UUDD) shear test, the consolidated undrained direct (CUDD) shear test, the unconsolidated undrained (UUD) triaxial test, the isotropically consolidated undrained (CUD) triaxial test, the isotropically consolidated drained (CD) triaxial test, the field vane test (vane), and the SPT. The tests were carried out according to Chinese national standards for soil laboratory test methods (NHRI 1999).

Table 2 summarizes the representative values of soil shear strength from laboratory tests carried out on soil samples ob- tained from the boreholes. In addition, Table 2 lists the soil compressibility and the SPT $N$ values. The test results clearly show that the recent marine deposits had extremely low shear strength values and high compressibility values. Analysis of the consolidation test results further reveals that the recent marine deposits were in a state of underconsolidation. The overconsolidation ratio was about 0.8 (Hou 1987). This underconsolidated characteristic of the marine mud is also reflected in the differences between the undrained and drained shear strength values in Table 2 . The undrained shear strength values obtained from the UUDD and UUD tests are much lower than those obtained from the CUDD, CUD, and CD tests. Such large differences may indicate that the laboratory tests with consolidation had significantly increased the shear strength of the underconsolidated soft marine mud.

A large number of field vane tests were carried out at the landslide zone to determine the undrained shear strength of the underconsolidated marine mud. The borehole locations for the field vane tests are shown in Fig. 7. Table 3 summarizes the test results at different elevations. Figure 16 shows the variation in undrained shear strength with elevation. Those tests were carried out before the landslide.

It is evident that the undrained shear strength from the field vane tests increased as elevation decreased. A linear regression equation for the variation of the average undrained 
Fig. 16. Variation of undrained shear strength (field vane) with elevation before the landslide. The data shown in this figure were obtained from boreholes M8, M10, M12, M14, L1, L3, L5, and L7, and their locations are shown in Fig. 7.

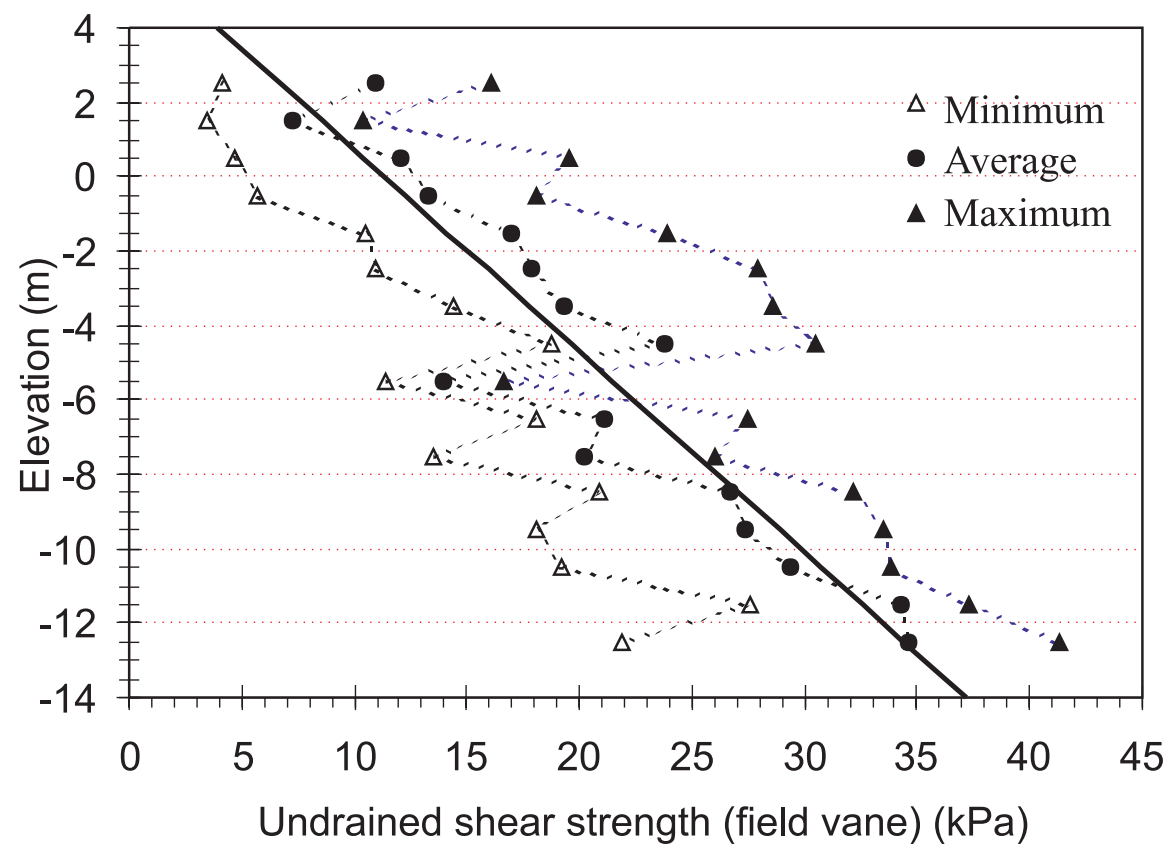

Table 3. Representative values of the undrained shear strength from field vane tests before the landslide.

\begin{tabular}{crllr}
\hline & & \multicolumn{3}{l}{ Undrained shear strength (field vane) } \\
\cline { 3 - 5 } $\begin{array}{l}\text { Test elevation } \\
\text { (m a.m.s.1.) }\end{array}$ & Test & $\begin{array}{l}\text { Maximum } \\
\text { value }(\mathrm{kPa})\end{array}$ & $\begin{array}{l}\text { Minimum } \\
\text { value }(\mathrm{kPa})\end{array}$ & $\begin{array}{r}\text { Avg. } \\
(\mathrm{kPa})\end{array}$ \\
\hline 3.0 to 2.0 & 5 & 16.1 & 4.1 & 10.9 \\
2.0 to 1.0 & 6 & 10.4 & 3.4 & 7.2 \\
1.0 to 0.0 & 5 & 19.5 & 4.7 & 12.1 \\
0.0 to -1.0 & 6 & 18.1 & 5.7 & 13.3 \\
-1.0 to -2.0 & 5 & 23.9 & 10.5 & 17.0 \\
-2.0 to -3.0 & 10 & 27.9 & 11.0 & 17.9 \\
-3.0 to -4.0 & 3 & 28.6 & 14.4 & 19.4 \\
-4.0 to -5.0 & 8 & 30.5 & 18.7 & 23.8 \\
-5.0 to -6.0 & 2 & 16.7 & 11.4 & 14.0 \\
-6.0 to -7.0 & 11 & 27.5 & 18.1 & 21.1 \\
-7.0 to -8.0 & 5 & 26.0 & 13.5 & 20.2 \\
-8.0 to -9.0 & 11 & 32.2 & 20.9 & 26.7 \\
-9.0 to -10.0 & 4 & 33.5 & 18.0 & 27.4 \\
-10.0 to -11.0 & 7 & 33.8 & 19.2 & 29.4 \\
-11.0 to -12.0 & 6 & 37.3 & 27.6 & 34.3 \\
-12.0 to -13.0 & 9 & 41.3 & 21.9 & 34.6 \\
\hline
\end{tabular}

Note: a.m.s.l., above mean sea level.

shear strength, $S_{\mathrm{u}}$, with elevation, $h$, can be expressed as follows:

[1] $S_{\mathrm{u}}=-1.85 h+11.32$

where the units of $S_{\mathrm{u}}$ and $h$ are kilopascals and metres, respectively; and the correlation coefficient of the regression, $R^{2}$, is 0.87 .

The residual values of the field vane shear resistance that were measured after the vane had been rotated several times indicate that the marine mud had a normal sensitivity of between 3.0 and 4.0.
Table 4. Recorded tide elevation at the Xingang Port in the morning of the landslide occurrence.

\begin{tabular}{ll}
\hline $\begin{array}{l}\text { Time on 17 September } \\
\text { 1997 }\end{array}$ & $\begin{array}{l}\text { Recorded tide elevation above the } \\
\text { standard sea level (m a.m.s.l.) }\end{array}$ \\
\hline $0: 00$ & +2.61 \\
$1: 00$ & +3.36 \\
$2: 00$ & +3.88 \\
$3: 00$ & +4.11 \\
$4: 00$ & +3.95 \\
$5: 00$ & +3.52 \\
$6: 00$ & +2.92 \\
$7: 00$ & +2.28 \\
$8: 00$ & +1.60 \\
$9: 00$ & +0.99 \\
$10: 00$ & +0.65 \\
$11: 00$ & +0.90 \\
$12: 00$ & +1.77 \\
\hline
\end{tabular}

Note: a.m.s.l., above mean sea level.

\section{Groundwater and tidal level during the landslide}

The reclaimed land had a shallow groundwater level. The average groundwater level was at an elevation of $+4.21 \mathrm{~m}$ a.m.s.l. For example, the groundwater level observed in one borehole was at about $+4.19 \mathrm{~m}$ a.m.s.l. over a $12 \mathrm{~h}$ period of continuous monitoring. The high groundwater level was due to the fact that the reclaimed land had a low permeability and that the tidal level could rise above $+4.00 \mathrm{~m}$ a.m.s.l. The reclaimed land was recently constructed by hydraulic filling of marine mud, and there was no engineering treatment for the very soft clayey fill.

The tide in Xingang Harbor belongs to the irregular semidiurnal category. Table 4 gives the recorded tidal elevations on the morning of the landslide occurrence, from mid- 
Fig. 17. A typical comparison between the undrained shear strength values determined with field vane tests in borehole M10 before the landslide and in borehole B6 after the landslide.

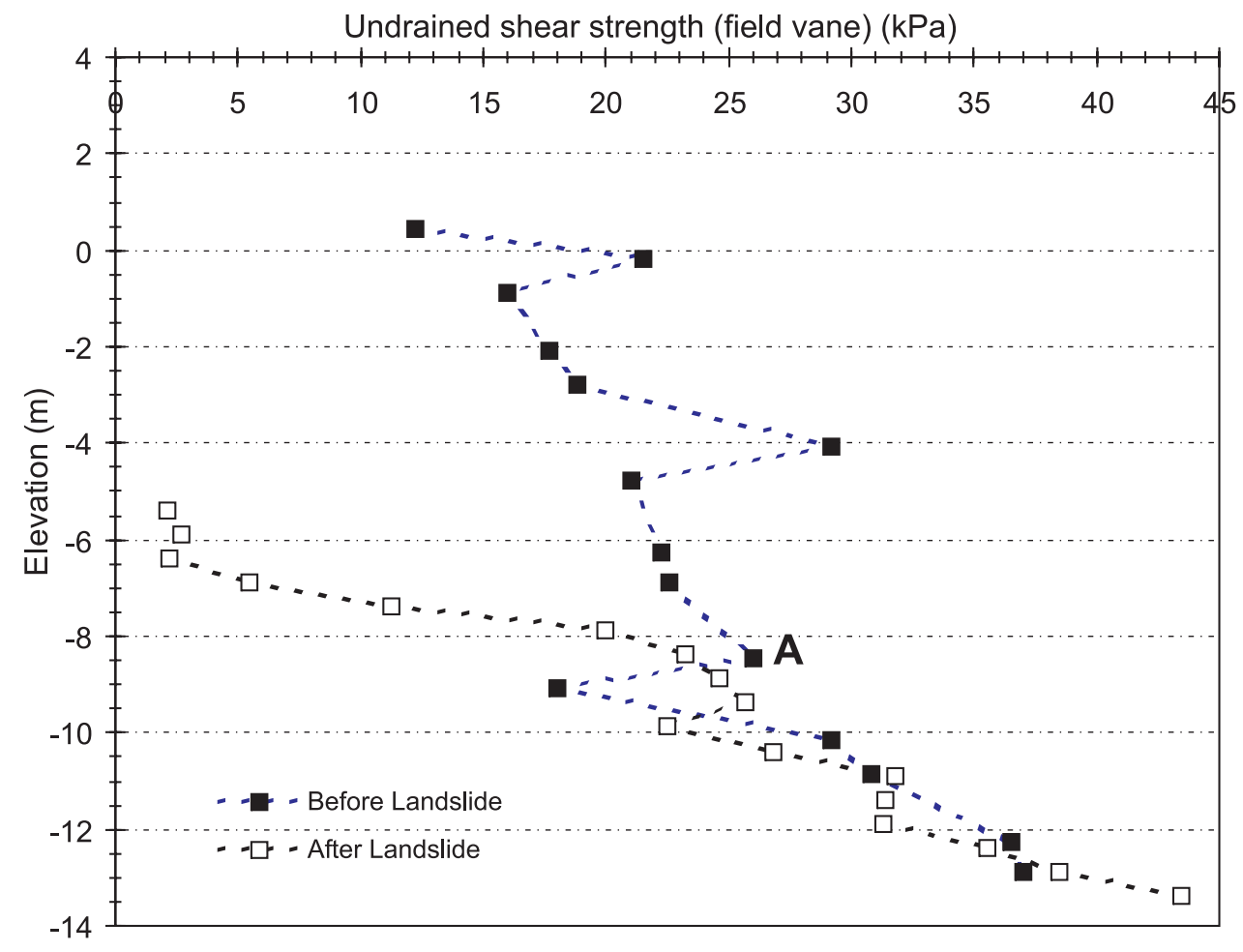

night to noon, on 17 September 1997. When the landslide happened, at 09:00 on the morning of 17 September, the tidal elevation had dropped from its highest level of $4.11 \mathrm{~m}$ a.m.s.l. at 03:00 to $+0.99 \mathrm{~m}$ a.m.s.l. The tidal elevation reached its lowest level, at $+0.65 \mathrm{~m}$ a.m.s.l., at 10:00. In other words, the landslide occurred during the lowest tide.

\section{Kinematic movement of the landslide}

As discussed above, the landslide was witnessed as having comprised a number of sequential slides that extended retrogressively and laterally toward the reclaimed land. Visual inspection of the site revealed many long and arcuate tension cracks and slipped terraces in the reclaimed land above the submerged landslide debris. These tension cracks and slipped terraces clearly show that the landslide debris in the land area consisted of a number of retrogressive slides with lateral spreading, although these slide bodies might have had a limited movement toward the seawater bay.

Furthermore, topographical survey results obtained before and after the landslide have also shown that the submerged landslide debris was deposited on both the failed slope and the berth base. It is therefore extremely important to examine whether there was a common rupture surface beneath the landslide debris and above the in situ marine mud for all the retrogressive slides. With this information, the kinematic movement of the multiple slides can be reconstructed with confidence.

\section{Rupture surface for retrogressive extension of failure into reclaimed land}

To determine whether there was a rupture surface for the retrogressive slope failure extension, we examined the vane shear test results and the borehole logs before and after the landslide. This examination revealed a rupture surface covered by landslide debris and seawater in the landslide zone.

The undrained shear strength values, measured with field vane tests before and after the landslide and at nearby locations, were examined and compared. Because the marine mud had a normal sensitivity of between 3 and 4, the peak undrained shear strength values of the failed mud should have been much lower than those of the original mud. A typical example of such examination and comparison is given in Fig. 17. It is evident from Fig. 17 that the peak undrained shear strength values before and after the landslide are almost the same below point $\mathrm{A}$ at elevation $-8 \mathrm{~m}$ a.m.s.l., whereas the peak vane shear strength values before the landslide are significantly greater than those after the landslide above point $\mathrm{A}$. The tests were carried out in borehole M10 before the landslide and in borehole B6 after the landslide. As shown in Fig. 7, the M10 and B6 locations were close to each other in the dredged slope, between cross sections B-B and $\mathrm{C}-\mathrm{C}$. As a result, it can be confirmed that point A was located on the rupture surface.

Furthermore, borehole $\operatorname{logs}$ from before and after the landslide were used in examining the rupture surface, because the soils above the slip surface should have been disturbed by the landslide. A typical example is given in Fig. 18, which compares the logs of boreholes M11 and B17. Borehole M11 was drilled before the landslide; and borehole B17, after the landslide. As shown in Fig. 7, the M11 and B17 locations were close to each other and also close to cross section $\mathrm{C}-\mathrm{C}$. The examination revealed that the soil above the mud sublayer and above elevation $-8.5 \mathrm{~m}$ a.m.s.l. had been substantially disturbed. The disturbed soil, which may be called muddy soil, did not have the same thin 
Fig. 18. A comparison between the soil strata in borehole M11 before the landslide and in borehole B17 after the landslide.

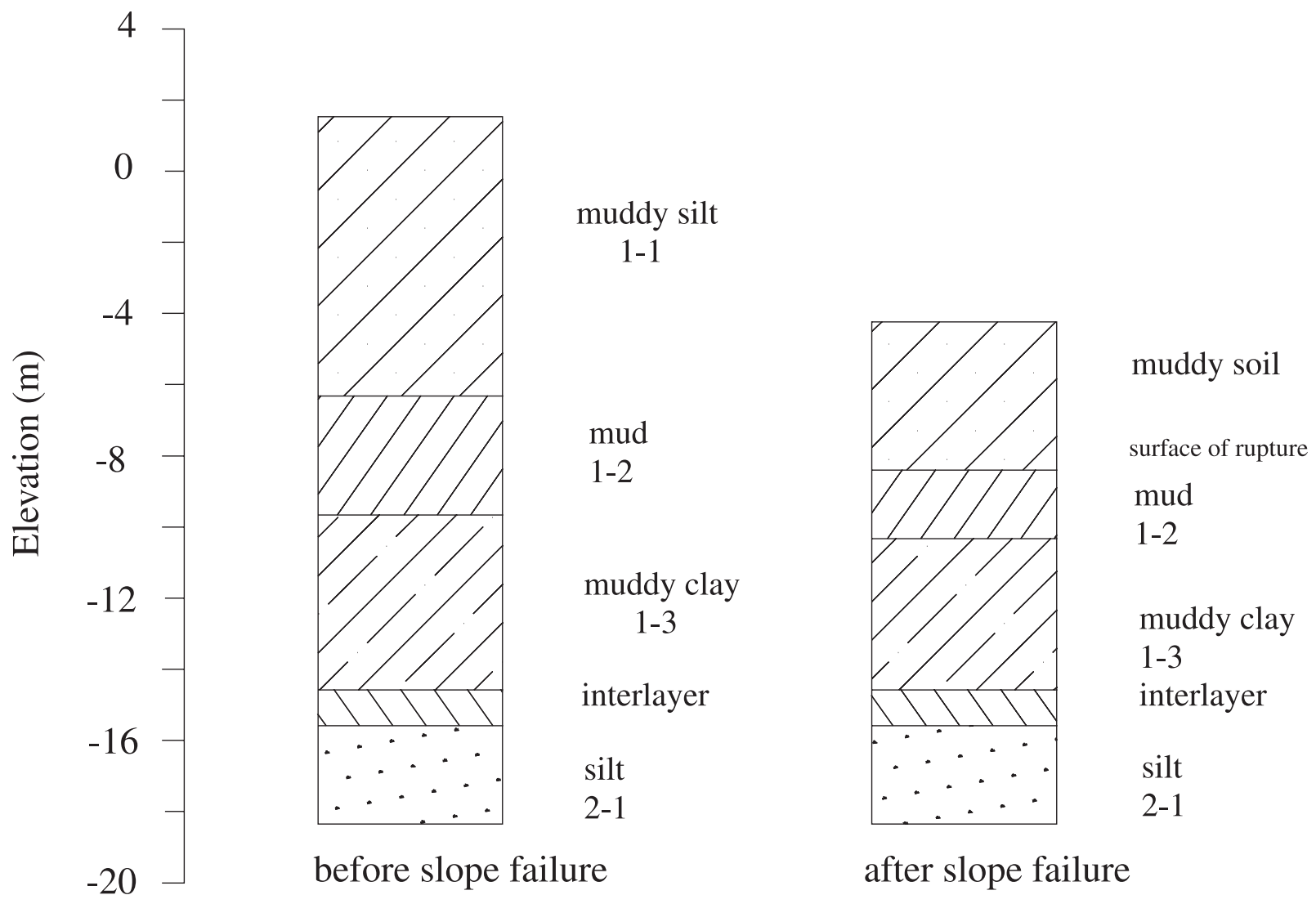

seam structural patterns as observed in the original mud. Below -8.5 m a.m.s.l., the soils in M11 and B17 had such structural patterns. Consequently, the rupture surface was at about $-8.5 \mathrm{~m}$ a.m.s.l. at this location.

Using the above two methods, we examined all the relevant field vane shear test results and borehole logs. The examinations led to the identification of the rupture surface beneath the landslide debris. Along cross sections B-B, C$\mathrm{C}$, and $\mathrm{D}-\mathrm{D}$ in the central region of the landslide zone in Fig. 7, the rupture surface was found to be quite similar. In this central region, the rupture surface was located at

(i) about -9.0 to $-12.0 \mathrm{~m}$ a.m.s.l. at the boundary line between the dredged slope and the berth, near borehole B2;

(ii) about -7.0 to $-8.0 \mathrm{~m}$ a.m.s.l. in the dredged slope near borehole D4;

(iii) about $-2.0 \mathrm{~m}$ a.m.s.l. at borehole B10; and

(iv) about $\pm 0.0 \mathrm{~m}$ a.m.s.l. behind borehole B10.

We further summarized the findings on the rupture surface along cross section $\mathrm{C}-\mathrm{C}$ in Fig. 19. The rupture surface was deep in the dredged slope region and became shallower and shallower as the distance to the dredged slope increased in the reclaimed land. It terminated at the boundary of the landslide zone (see Figs. 3 and 7). The rupture surface was about $200 \mathrm{~m}$ long and had a very gentle slope of about $3.3^{\circ}$. In Fig. 19, we also present the ground surface profiles, from before and after the dredging, and the profile of the landslide debris. The landslide debris was located below the ground surface after the slope failure above the rupture surface.

The rupture surface became shallower and shallower as it neared the eastern and western boundaries of the landslide zone. Cross sections $\mathrm{A}-\mathrm{A}$ and $\mathrm{E}-\mathrm{E}$ had similar rupture surfaces. The surfaces of rupture along cross sections A-A and $\mathrm{E}-\mathrm{E}$ were at about $-4.0 \mathrm{~m}$ a.m.s.l. in the submerged region and about +1.0 to $+2.0 \mathrm{~m}$ a.m.s.l. in the slipped land. Using cross section $\mathrm{E}-\mathrm{E}$ as the representative section, we summarized the findings of the landslide investigation in Fig. 20. The rupture surface began at the middle level of the dredged slope and became shallower and shallower as the distance to the dredged slope increased in the reclaimed land. It also terminated at the boundary of the landslide zone. It was about $140 \mathrm{~m}$ long and had an overall slope of about $4.0^{\circ}$. Similarly, in this figure, we also present the ground surface profiles from before and after the dredging, as well as the profile of the landslide debris. The landslide debris was located below the ground surface after the slope failure above the rupture surface.

To examine the lateral spreading of the landslide, we present two additional cross sections, F-F and G-G in Figs. 21 and 22, respectively. As shown in Fig. 7, these two cross sections are parallel to the shoreline and perpendicular to the main direction of the landslide movement. Cross section F-F is located below the dredged slope crest; and cross section $\mathrm{G}-\mathrm{G}$, at the middle of the landslide zone behind the dam. The rupture surfaces in these two cross sections were deeper in the central region and gradually rose to the ground surface at the two side boundaries. The rupture surface in cross section $\mathrm{F}-\mathrm{F}$ was generally much deeper than that in cross section $\mathrm{G}-\mathrm{G}$. In these two figures, we also present the ground surface profiles from before and after the dredging, as well 

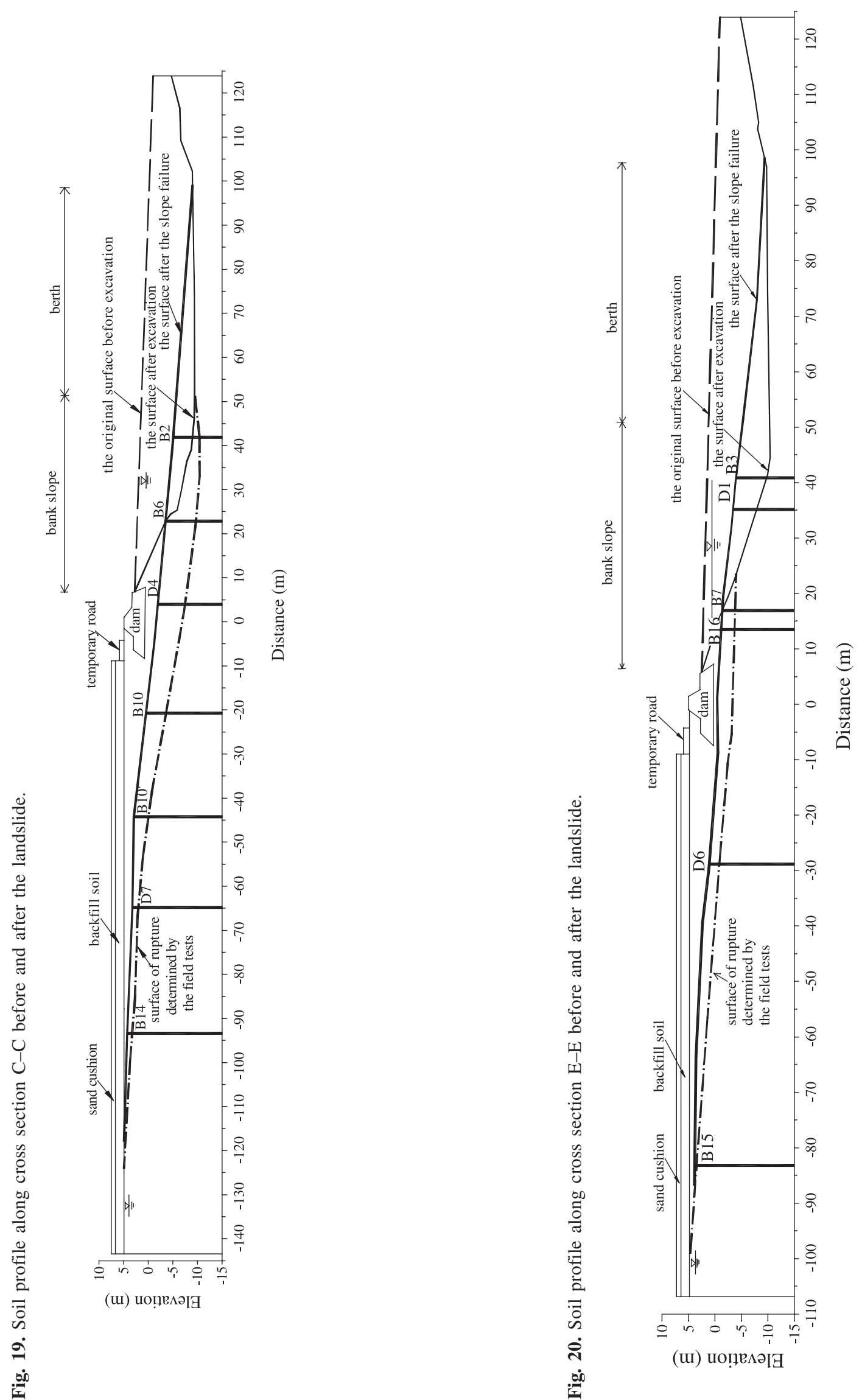

(C) 2005 NRC Canada 
Fig. 21. Soil profile along cross section F-F before and after the landslide.

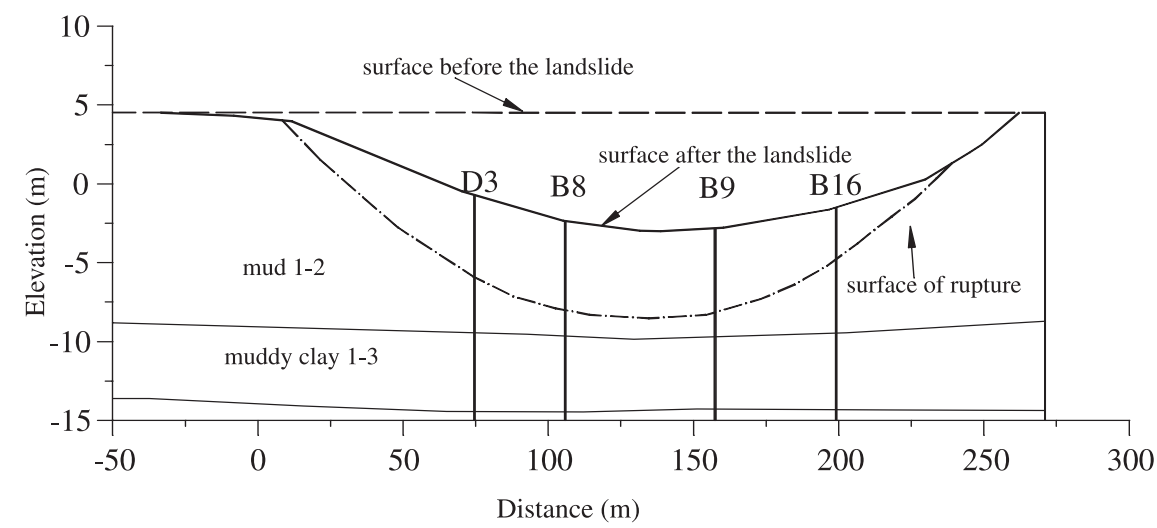

Fig. 22. Soil profile along cross section $\mathrm{G}-\mathrm{G}$ before and after the landslide.

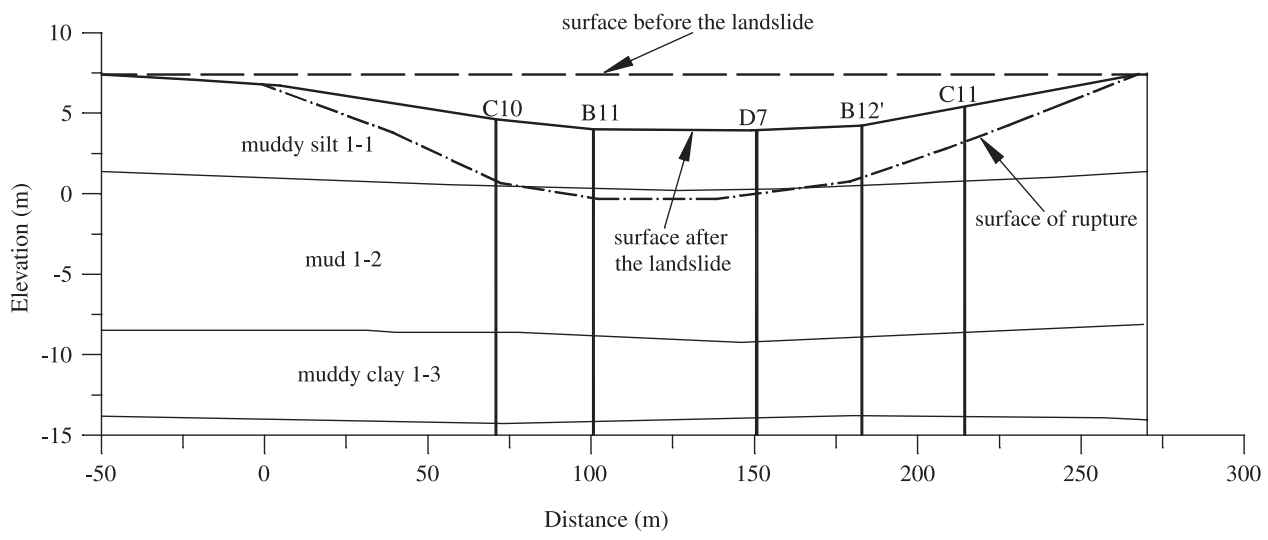

as the profile of the landslide debris. The landslide debris was located below the ground surface after the slope failure, above the rupture surface.

The volume of the failed soil mass in the reclaimed land and behind the dredged slope could then be estimated using the original ground surface profile after the dredge excavation and the rupture surface for the landslide. The volume was thus estimated to be between 700000 and $800000 \mathrm{~m}^{3}$.

\section{Kinematic movement}

In the above discussions, we have shown that the landslide consisted of a number of individual slides. These slides occurred sequentially and extended retrogressively and laterally into the reclaimed land. They shared a common rupture surface. The first slide in the dredged slope rendered the remaining reclaimed land unstable, which then failed progressively. The rupture surface had the important feature that its depth became shallower and shallower and its slope angle became gentler and gentler as its distance to the dredged slope increased in the reclaimed land. This feature revealed that the unstable reclaimed land became shallower and shallower and the slipped soil body became thinner and thinner as the failure extended retrogressively and laterally into the reclaimed land. Consequently, the kinetic energy of each individual slipped soil mass became less and less, and the slide debris was then deposited more and more on the previously failed areas. Eventually, the last failed soil masses had very limited travel distance and formed slipped terraces that were associated with tension cracks in the reclaimed land.
On the basis of the above discussions and findings, we reconstructed the model of slide extensions into the reclaimed land in Fig. 23. Basically, the landslide started when the first slide occurred. Subsequently, the second slide occurred. Then the third slide occurred. Other slides continued to occur in sequence until the last slide occurred at the observed boundary of the landslide zone in the reclaimed land. In Fig. 23, the first slide crest line was based on the observations of witnesses (see Fig. 3). The last few slide crest lines were based on field inspection of the reclaimed land (e.g., Figs. 5, 6, 8-11). The second to fifth slide crest lines were inferred from the relevant data and the analytical studies presented in the companion paper (Li et al. 2005).

\section{Summary and conclusions}

In this paper, we have presented the field investigation of a major landslide that occurred in a dredged slope that comprised underconsolidated soft soil and was largely submerged in seawater. Factual data have been presented, including site geological setting, port design and construction, topographical survey results from before and after the landslide, witness observations, visual inspection after the landslide, ground investigations before and after the landslide, soil properties and undrained and drained shear strength values from laboratory and field tests, and groundwater and tidal levels during the landslide. On the basis of such factual data, we have located a rupture surface beneath the displaced material and above the in situ marine mud. We 
Fig. 23. Inferred kinematical model of failure extension into the reclaimed land during the landslide.

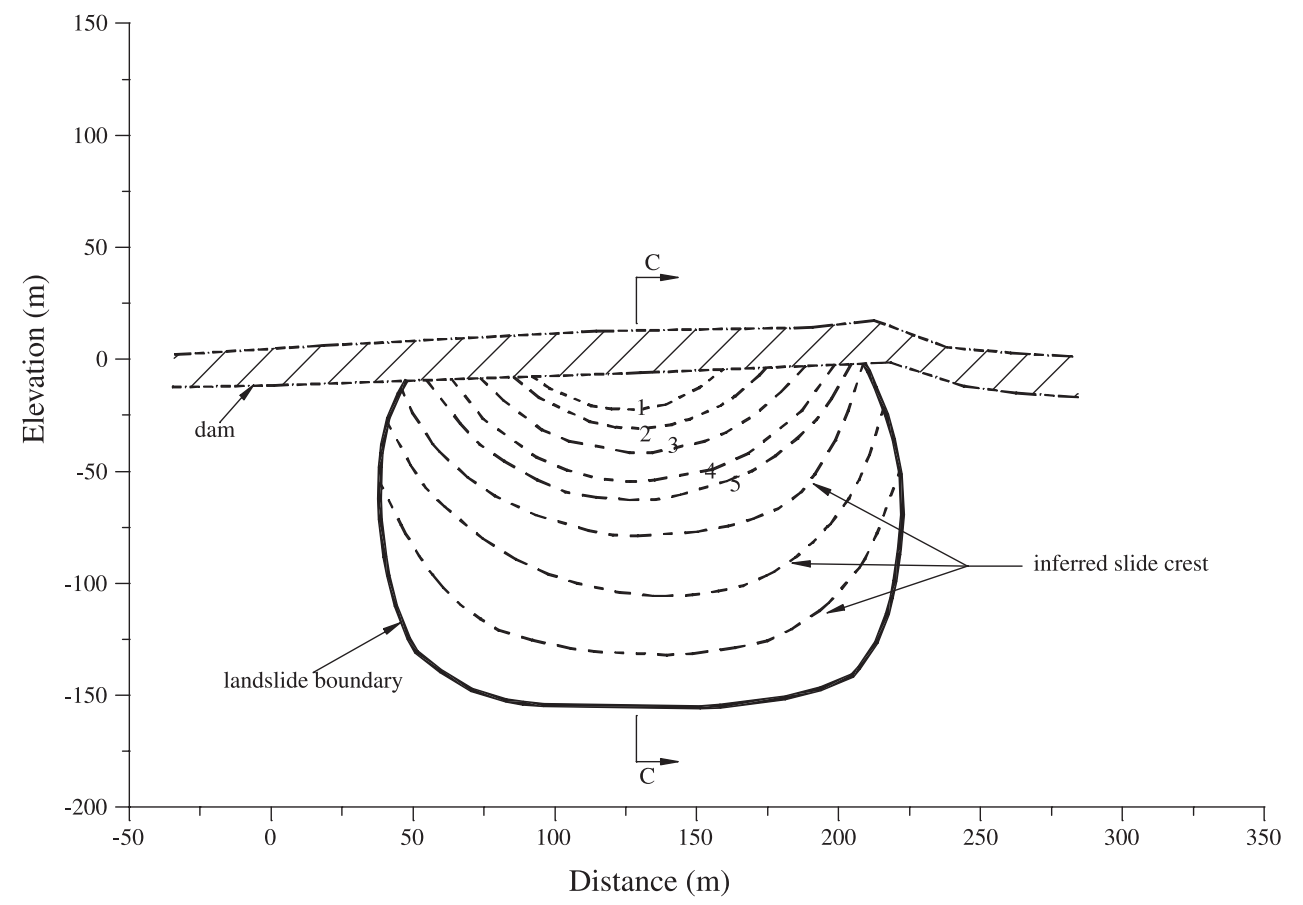

have further reconstructed a kinematic model to show the possible extension of the individual slides into the reclaimed land. We have discussed the kinematic mechanism for the extension and termination of the individual slides.

We have found that the landslide consisted of a number of individual slides that occurred sequentially and extended into the reclaimed land progressively and laterally. The failed soil mass comprised mainly recent marine mud and man-made fills. The marine mud was an underconsolidated soft soil and had low shear strength and permeability. In particular, we have found that the undrained shear strength values from field vane tests and the borehole logs from before and after the landslide can give excellent factual data for the determination of the rupture surface for the landslide. The rupture surface occupied an inclined area of between 27000 and $30000 \mathrm{~m}^{2}$. Its overall slope was estimated to be about $3-4^{\circ}$. Its depth became shallower and shallower as the distance from the dredged slope crest increased in the reclaimed land. The landslide occupied a plan area of about $30000 \mathrm{~m}^{2}$ in the reclaimed land. The volume of the failed soil mass was estimated to be between 700000 and $800000 \mathrm{~m}^{3}$. Part of the failed soils slipped into the berth and occupied a volume of between 45000 and $60000 \mathrm{~m}^{3}$ and a plan area of between 22000 and $30000 \mathrm{~m}^{2}$ on the berth base. The angle from the dredged slope crest to the far front of the landslide debris was about $6.8^{\circ}$. The landslide debris surface had an overall slope of about $3.0^{\circ}$. Finally, it is noted that although they were tilted as a result of the soil movement, the 55 driven piles could have had a stabilizing effect on the western part of the dredged slope. As a result, the soils in this western part had much less movement toward the berth.

\section{Acknowledgements}

The authors would like to acknowledge the financial sup- port of the Research Grants Council of the Hong Kong Special Administrative Region of the People's Republic of China and the Hong Kong Jockey Club Charities Trust. The authors thank the editor, Professor A.J. Valsangkar, the associate editor, and two peer reviewers for their valuable comments and suggestions, which enhanced the presentation of the paper.

\section{References}

Broms, B.B., and Wong, K.S. 1991. Landslides. In Foundation engineering handbook. 2nd ed. Edited by H.Y. Fang. Kluwer Academic Publishers, London, U.K. pp. 410-435.

BSI. 1988. Design of quay walls, jetties and dolphins (BS6349Part 2: 1988). British Standards Institution (BSI). London, U.K.

BSI. 2000. Maritime structures-Part I: Code of practice for general criteria (BS6349-Part 1: 2000). British Standards Institution (BSI), London, U.K.

CEO. 2002. Port works manual - design, construction and maintenance. Civil Engineering Office (CEO), Department of Civil Engineering, Government of Hong Kong, Hong Kong.

Endicott, J. 2001. Drained reclamation in Hong Kong. In Proceedings of the 3rd International Conference on Soft Soil Engineering, 6-8 December 2001, Hong Kong. Edited by C.F. Lee, C.K. Lau, C.W.W. Ng, A.K.L. Kwong, P.L.R. Pang, J.-H. Yin, and Z.Q. Yue. A.A. Balkema Publishers, Tokyo. pp. 3-11.

Fang, H.Y., and Mikroudis, G.K. 1991. Stability of earth slopes. In Foundation engineering handbook. 2nd ed. Edited by H.Y. Fang. Kluwer Academic Publishers, London, U.K. pp. 379-409.

GCO. 1984a. Investigation of a failure at Junk Bay controlled tip. Geotechnical Control Office (GCO), Engineering Development Department, Government of Hong Kong, Hong Kong. Advisory Report ADR 17/84.

GCO. 1984b. Geotechnical manual for slopes. Geotechnical Control Office (GCO), Engineering Development Department, Government of Hong Kong, Hong Kong. 
Hou, Z. (Editor). 1987. Tianjin soft soil foundations. Tianjin Science \& Technology Press, Tianjin, China. [In Chinese.]

Janbu, N. 1977. Slopes and excavations in normally and lightly overconsolidated clays. In Proceedings of the 9th International Conference on Soil Mechanics and Foundation Engineering, Tokyo. Vol. 2, pp. 549-566.

Lacasse, S. 2001. Parameters for soft clays. In Proceedings of the 3rd International Conference on Soft Soil Engineering, 68 December 2001, Hong Kong. Edited by C.F. Lee, C.K. Lau, C.W.W. Ng, A.K.L. Kwong, P.L.R. Pang, J.-H. Yin, and Z.Q. Yue. A.A. Balkema Publishers, Tokyo. pp. 25-36.

Lam, B.M.T., and Leung, B.N. 1992. Ma On Shan area 77, reclamation failure. In Proceedings of the Seminar on Sha Tin New Town Development. Hong Kong, November, Hong Kong Institution of Engineers. pp. 85-100.

Lee, C.F., Lau, C.K., Ng, C.W.W., Kwong, A.K.L., Pang, P.L.R., Yin, J.-H., and Yue, Z.Q. (Editors). 2001. Proceedings of the 3rd International Conference on Soft Soil Engineering, 6-8 December 2001, Hong Kong. A.A. Balkema Publishers, Tokyo.

Lefebvre, G. 1981. Strength and slope stability in Canadian soft clay deposits. Canadian Geotechnical Journal, 18: 420-442.

Li, S., Yue, Z.Q., Tham, L.G., Lee, C.F., and Yan, S.W. 2005. Slope failure in underconsolidated soft soils during the development of a port in Tianjin, China. Part 2: Analytical study. Canadian Geotechnical Journal, 42: 166-183.
Morgenstern, N. 1963. Stability charts for earth slopes during rapid drawdown. Géotechnique, 13: 121-131.

NHRI. 1999. National standards of soil test methods (GB/T 501231999). Nanjing Hydraulic Research Institute (NHRI), Ministry of Construction of China, Planning Publishing House, Beijing, China. [In Chinese.]

Roy, M., and Leblanc, A. 1988. Factors affecting the measurements and interpretation of the vane strength in soft sensitive clays. In Vane shear strength testing in soils: field and laboratory studies. Edited by A.F. Richards. American Society for Testing and Materials. Philadelphia, Pa. ASTM Special Technical Publication 1014, pp. 117-128.

Skempton, A.W. 1977. Slope stability of cuttings in London clay. In Proceedings of the 9th International Conference on Soil Mechanics and Foundation Engineering, Tokyo. Vol. 3, pp. 261270.

Tsinker, G.P. 1997. Handbook of port and harbour engineering: Geotechnical and structural aspects. Chapman \& Hall, London, U.K.

Yue, Z.Q., and Lee, C.F. 2002. A plane slide that occurred during construction of a national expressway in Chongqing, southwestern China. Quarterly Journal of Engineering Geology and Hydrogeology, 35: 309-316. 